\title{
Intradiurnal and seasonal variability of soil temperature, heat flux, soil moisture content, and thermal properties under forest and pasture in Rondônia
}

\author{
R. C. S. Alvalá, ${ }^{1}$ R. Gielow, ${ }^{1}$ H. R. da Rocha, ${ }^{2}$ H. C. Freitas, ${ }^{2}$ J. M. Lopes,${ }^{2}$ \\ A. O. Manzi, ${ }^{3}$ C. von Randow, ${ }^{3}$ M. A. F. S. Dias, ${ }^{2}$ O. M. R. Cabral, ${ }^{4}$ \\ and M. J. Waterloo ${ }^{5}$
}

Received 6 March 2001; revised 3 December 2001; accepted 15 January 2002; published 23 August 2002.

[1] Soil temperatures depend on the soil heat flux, an important parameter in meteorological and plant growth-energy balance models. Thus, they were measured, together with soil moisture contents, within the LBA program at forest (Reserva Jaru) and pasture (Fazenda Nossa Senhora) sites in Rondônia, Brazilian Amazonia during wet (February) and dry (August) periods of 1999. The wet period showed maxima of the heat flux into the soil around five to six times smaller at the forest than at the pasture, except for some spikes that are related to stronger solar forcing, such as those due to sunspecks in the forest. This pattern remained during the dry period, but with doubled maximum values. Also, the soil heat flux and the soil temperatures responded very significantly to the passage of cold fronts in both periods at both sites. Temperature profiles measured in the $0.10-0.40 \mathrm{~m}$ soil layer showed daily averages and ranges smaller at the forest than at the pasture. The daily average of the soil moisture content in the same layer, during the wet season, increased with depth at both sites, with consistently lower values at the forest. However, their ranges were smaller at the pasture, except for the $0.40 \mathrm{~m}$ depth. During the dry period, these ranges were much higher at the pasture, but with nearer average values. Finally, the computed daily apparent soil thermal diffusivities, volumetric heat contents, and thermal conductivities are presented, with the first ones crossed with the measured soil moisture content. INDEX TERMS: 3322 Meteorology and Atmospheric Dynamics: Land/atmosphere interactions; KEYWORDS: soil temperature, soil heat flux, soil moisture content, soil thermal properties, soil thermal diffusivity, Amazon

\section{Introduction}

[2] Heat and moisture exchanges between the ground surface and the atmosphere are frequently dominant driving mechanisms for mesoscale circulations. These surface processes are included in weather forecast model physics by specifying different lower boundary conditions, which depend on the soil and surface characteristics, thus presenting spatial variation. Over land, significant diurnal changes of temperature and moisture balance near the interface with the atmosphere also occur [Smith et al., 1994; Smirnova et al., 1997]. In particular, the prediction of the ground surface temperature and moisture content is critical to obtain successful forecasts of the above mentioned exchanges.

\footnotetext{
${ }^{1}$ Centro de Previsão de Tempo e Estudos Climáticos, Instituto Nacional de Pesquisas Espaciais, São José dos Campos, SP, Brazil.

${ }^{2}$ Instituto de Geofísica, Astronomia e Ciências da Atmosfera, Universidade de São Paulo, São Paulo, SP, Brazil.

${ }^{3}$ Centro de Previsão de Tempo e Estudos Climáticos, Instituto Nacional de Pesquisas Espaciais, Cachoeira Paulista, SP, Brazil.

${ }^{4}$ Centro Nacional de Pesquisas do Meio Ambiente, Empresa Brasileira de Pesquisa Agropecuária, Jaguariúna, SP, Brazil.

${ }^{5}$ Vrije Universiteit Amsterdam, Amsterdam, Netherlands.

[3] Coupled models of heat and moisture transport in bare soils [Novak and Black, 1985; Passerat de Silans et al., 1989] or in vegetated soils [Braud et al., 1994; Smirnova et al., 1997] require information about soil thermal properties, such as thermal conductivity, thermal diffusivity, and volumetric heat capacity, which are used to determine temperature profiles and heat flux in the soil. These properties [de Vries, 1966] are dependent on soil moisture content, soil composition and structure, and vegetation cover (shading, root influence on soil moisture content). Notwithstanding, the determination of these data based on field measurements, especially as a function of water content, such as those presented by Verhoef et al. [1996], are currently not readily available, despite their increasing demand, due to more detailed requirements of the transport models.

[4] The soil thermal properties, due to their dependency on the soil moisture content, vary both in space and in time causing two types of heterogeneity [Verhoef et al., 1996]. A mesoscale heterogeneity that can be induced by spatially variable rainfall which influences these properties (and thus the soil heat flux and temperature) through changes in soil moisture content on a scale of several kilometers. Second, a heterogeneity on the microscale, which depends on the conditions of the surface, that is, bare or covered with vegetation. The cover may be dense 
Table 1. Forest and Pasture Soil Granulometric Analyses and Organic Matter Content

\begin{tabular}{|c|c|c|c|c|c|c|c|c|c|c|}
\hline \multirow[b]{2}{*}{$\begin{array}{c}\text { Soil sample } \\
\text { depth, } \\
\text { m }\end{array}$} & \multicolumn{5}{|c|}{ Forest } & \multicolumn{5}{|c|}{ Pasture } \\
\hline & $\begin{array}{c}\text { Number } \\
\text { of } \\
\text { Samples }\end{array}$ & $\begin{array}{c}\text { Sand } \\
\%\end{array}$ & $\begin{array}{c}\text { Silt } \\
\%\end{array}$ & $\begin{array}{c}\text { Clay } \\
\%\end{array}$ & $\begin{array}{c}\text { Organic } \\
\text { Matter } \\
\% \\
\end{array}$ & $\begin{array}{c}\text { Number } \\
\text { of } \\
\text { Samples }\end{array}$ & $\begin{array}{c}\text { Sand } \\
\%\end{array}$ & $\begin{array}{c}\text { Silt } \\
\%\end{array}$ & $\begin{array}{c}\text { Clay } \\
\%\end{array}$ & $\begin{array}{c}\text { Organic } \\
\text { Matter } \\
\% \\
\end{array}$ \\
\hline $0-0.050$ & 4 & $87.2 \pm 1.1$ & $2.6 \pm 0.5$ & $10.2 \pm 1.0$ & $1.59 \pm 0.14$ & 7 & $83.0 \pm 7.4$ & $6.3 \pm 5.9$ & $10.7 \pm 1.8$ & $2.0 \pm 0.2$ \\
\hline $0.075-0.125$ & 1 & 81.4 & 3.4 & 15.2 & 1.74 & 4 & $87.4 \pm 2.0$ & $2.3 \pm 1.6$ & $10.3 \pm 0.5$ & $1.9 \pm 0.1$ \\
\hline $0.175-0.225$ & 1 & 74.3 & 3.6 & 22.1 & 1.76 & 4 & $84.2 \pm 3.6$ & $4.1 \pm 2.1$ & $11.7 \pm 1.5$ & $2.0 \pm 0.1$ \\
\hline $0.375-0.425$ & 1 & 73.8 & 3.5 & 22.7 & 1.83 & 4 & $81.0 \pm 4.8$ & $2.6 \pm 0.6$ & $16.4 \pm 4.7$ & $2.0 \pm 0.2$ \\
\hline
\end{tabular}

or present different degrees of sparseness. This will influence the underlying soil by shading it homogeneously or not, with influence on the soil moisture, and thus the soil thermal properties. Besides these spatial variations, large temporal variations occur if heavy rainfall is alternated by dry periods.

[5] Also, all of the physical, chemical, and the biological processes which occur in the soil are influenced by the soil temperature and moisture content, and their gradients. Biological processes such as the uptake of nutrients and water by roots, the decomposition of organic matter by microbes and the germination of seeds are strongly affected by them. Rates of some of these processes more than double for each $10 \mathrm{~K}$ increase in temperature. In some cases, growth of aboveground plant parts is more closely correlated with soil temperature than with air temperature. Physical processes, such as water movement and soil drying can also be strongly influenced by temperature [Campbell, 1985].

[6] Over the past twenty five years there has been an increase of the conversion of the world's tropical forests to other uses. Concerning the Brazilian Amazon rain forest, a vast area has been changed, mainly due to slash and burn actions, into pasture or agricultural land [INPE, 1999]. This change produces significant alterations in the soil-vegetation-atmosphere interactions and, consequently, in the weather and climate.

[7] So, this paper describes the intradiurnal and seasonal variability of soil temperature, heat flux and moisture content during wet and dry periods, as well as some aspects of the dry-wet transition period, all measured in 1999 at forest (Reserva Jaru) and pasture (Fazenda Nossa Senhora) sites in Rondônia, Brazilian Amazonia, within the WETAM/LBA project and its subsequent field observations. Also, corresponding computed values of thermal properties of the soil are presented.

\section{Sites Descriptions, Soil Characteristics, and Field Measurements}

[8] The data were collected at the pasture site on the Nossa Senhora farm, NS $\left(10^{\circ} 45^{\prime} \mathrm{S}, 62^{\circ} 22^{\prime} \mathrm{W}\right)$ and in the forest of the Reserva Biológica do Jaru, RJ $\left(10^{\circ} 46^{\prime} \mathrm{S}\right.$, $\left.61^{\circ} 56^{\prime} \mathrm{W}\right)$, both located near Ji-Paraná in the state of Rondônia, in the western part of Brazil. The Nossa Senhora farm is a cattle ranch $220 \mathrm{~m}$ above sea level about $50 \mathrm{~km}$ north east of Ji-Paraná, which was deforested about twenty five years ago. This farm is situated in a strip of land cleared by slash and burn, about $4 \mathrm{~km}$ wide and several tens of kilometers long, in the center of an area of about $50 \mathrm{~km}$ in radius, which has been largely cleared and covered with grass [Brachiaria brizantha (A. Rich.) Stafp]. Reserva Jaru is a forest reserve owned by the Brazilian Environmental Protection Agency (Instituto Brasileiro de Meio Ambiente e Recursos Renováveis, IBAMA), and is located about $80 \mathrm{~km}$ north of Ji-Paraná at $120 \mathrm{~m}$ above sea level. Both sites originally had the same vegetation cover, classified as open rain forest, with a $30 \mathrm{~m}$ mean canopy-top height. Soils are classified in both sites as medium textured red-yellow podzols (Podzólico vermelho-amarelo A moderado textura média, Brazil, typic paleudult, Soil Taxonomy, or orthic acrisol, FAO). The granulometric analyses of samples taken in both sites from the surface down to the $0.425 \mathrm{~m}$ depth (Table 1) showed more than $80 \%$ of sand for most of them, thus classifying them either as loamy sand or sand loams; the two exceptions, with ca. $74 \%$ of sand (sandy clay loams), are from the forest. The similarity among the samples taken below $0.075 \mathrm{~m}$ was shown by their organic matter content between 1.7 and $2.0 \%$ (Table 1 ), and by their dry bulk densities $(\rho)$ range between 1500 and $1620 \mathrm{~kg} \mathrm{~m}^{-3}$, with the corresponding porosities between 43.4 and $39.0 \%$ (Table 2). More details of the vegetation and soil at both sites are given by McWilliam et al. [1996] and by Hodnett et al. [1996], respectively. Also, Calvet et al. [1997] present digital maps of the vegetation, soil and relief for Rondônia, Brazil, based on 1:1,000,000 paper maps, as well as satellite information about modifications of the surface due to human activities.

[9] The main observation periods considered in the present study, (1) February and (2) August 1999, represent the end of both the rainy and the dry seasons, while (3) September 1999 constitutes the transition from dry to rainy season in the region considered.

[10] Two profiles of soil temperatures in both pasture and forest were sampled with Campbell Scientific thermistors

Table 2. Forest and Pasture Soil Densities and Porosities

\begin{tabular}{lccccc}
\hline & \multicolumn{2}{c}{ Forest } & & \multicolumn{2}{c}{ Pasture } \\
\cline { 2 - 3 } \cline { 5 - 6 } $\begin{array}{c}\text { Soil sample depth, } \\
\text { m }\end{array}$ & $\begin{array}{c}\text { Dry bulk density }(\rho) \\
10^{3}, \mathrm{~kg} / \mathrm{m}^{3}\end{array}$ & $\begin{array}{c}\text { Porosity } \\
\%\end{array}$ & & $\begin{array}{c}\text { Dry bulk density }(\rho) \\
10^{3}, \mathrm{~kg} / \mathrm{m}^{3}\end{array}$ & $\begin{array}{c}\text { Porosity } \\
\%\end{array}$ \\
\hline $0-0.050$ & $1.18 \pm 0.06$ & $55.4 \pm 2.2$ & & $1.39 \pm 0.12$ & $48.2 \pm 4.8$ \\
$0.75-0.125$ & 1.50 & 43.4 & & $1.52 \pm 0.18$ & $42.0 \pm 7.4$ \\
$0.175-0.225$ & 1.55 & 41.5 & & $1.59 \pm 0.03$ & $40.1 \pm 1.2$ \\
$0.375-0.425$ & 1.56 & 41.1 & & $1.62 \pm 0.13$ & $39.0 \pm 5.0$ \\
\hline
\end{tabular}


Table 3. Gravimetric Versus FDR Soil Moisture Contents

\begin{tabular}{lccccc}
\hline Site & Depth, $\mathrm{m}$ & DOY-LST & $\begin{array}{c}\theta \text { (gravimetric) } \\
\mathrm{m}^{3} \mathrm{~m}^{-3}\end{array}$ & $\theta$ (FDR), $\mathrm{m}^{3} \mathrm{~m}^{-3}$ & FDR/gravimetric \\
\hline Forest & 0.10 & $54-1525$ & 0.23 & 0.22 & 0.96 \\
& 0.20 & $54-1545$ & 0.25 & 0.23 & 0.92 \\
Pasture & 0.40 & $54-1740$ & 0.22 & 0.24 & 1.09 \\
& 0.10 & $33-1220$ & 0.23 & 0.20 & 0.87 \\
& 0.20 & $33-1210$ & 0.22 & 0.23 & 1.04 \\
& 0.40 & $33-1600$ & 0.26 & 0.25 & 0.96 \\
& & & & Average 0.97 \\
\hline
\end{tabular}

DOY, day of the year.

(Logan, UT, USA), with the recording of 10 min averages effected with Campbell CR10X data loggers. At the pasture the soil temperatures were measured at three depths: 0.10 , 0.20 , and $0.40 \mathrm{~m}$, while at the forest one profile was measured at the same three depths, and the second at two depths: 0.10 and $0.20 \mathrm{~m}$; at the forest, their position was about equidistant from the surrounding tree trunks. This number of measurements was chosen considering the availability of equipment and the logistic difficulties inherent to the remoteness of the sites. Further, the depths were selected to obtain data in a soil layer with strong biological activities, in which the signature of the daily energy cycle is well defined with three time series.

[11] The soil heat flux was measured with Campbell heat flux plates at both sites at the $0.02 \mathrm{~m}$ depth, to sense it practically at the soil-atmosphere interface. The incident and reflected solar radiations were measured with Kipp and Zonen solarimeters (Delft, the Netherlands), the net radiation was obtained with REBS net radiometers (Seattle, WA, USA), and the air temperature and relative humidity were measured with an HMP45C-L150 thermohygrometer (Vaisala, Finland). These instruments were installed on aluminum towers, at the heights of $6.72 \mathrm{~m}$ in the pasture site and of $58.35 \mathrm{~m}$ in the forest site, respectively. The rainfall was measured at both sites with $0.2 \mathrm{~mm}$ resolution tipping bucket raingauges from Didcot (Abingdon, UK).

[12] The soil moisture content $(\theta)$ was sampled by frequency domain reflectometry, FDR, sensors (FDR Campbell Systems CS615 sensors, Logan, UT, USA) at the same three depths of the temperature measurements: $0.10,0.20$, and $0.40 \mathrm{~m}$. These sensors were installed at most $2 \mathrm{~m}$ away from the ones for the temperature. Two profiles were measured at the pasture and one at the forest, with a data acquisition rate of $10 \mathrm{~min}$ averages. The calibration curves for the FDRs were adjusted through laboratory tests using undisturbed soil samples $(0.10 \mathrm{~m} \times 0.10 \mathrm{~m} \times 0.40 \mathrm{~m}$ slabs $)$ from both sites, resulting the following expressions:

$$
\begin{aligned}
& \text { Forest } \\
& \theta=-1.955 t^{3}+5.641 t^{2}-4.608 t+1.135 \\
& \text { Pasture } \quad \theta=-4.320 t^{3}+12.269 t^{2}-10.690 t+2.915
\end{aligned}
$$

where $t$ is the response time in ms. The squared correlation coefficient $\left(\mathrm{R}^{2}\right)$ were equal to 0.99 for each site, in the ranges of the field measurements (forest: $0.04 \mathrm{~m}^{3} \mathrm{~m}^{-3} \leq \theta$ $\leq 0.34 \mathrm{~m}^{3} \mathrm{~m}^{-3}$; pasture: $0.02 \mathrm{~m}^{3} \mathrm{~m}^{-3} \leq \theta \leq 0.29 \mathrm{~m}^{3} \mathrm{~m}^{-3}$ ). The difference between both calibrations, notwithstanding the similarity of the soils, may be due, in part, to differences in their chemical composition, which may alter their electrical conductivities and, thus, $t$. The concentrations of exchangeable $\mathrm{P}, \mathrm{K}, \mathrm{Ca}$ and $\mathrm{Mg}$, determined in the same samples mentioned in Table 1, are approximately between two and four times lower at the forest than at the pasture, that is: $\mathrm{P}-1.61( \pm 0.42) \mathrm{mg} \mathrm{dm}^{-3}$ versus $3.29( \pm 0.69) \mathrm{mg}$ $\mathrm{dm}^{-3} ; \mathrm{K}-0.08( \pm 0.02) \mathrm{cmol} \mathrm{dm}^{-3}$ versus $0.15( \pm 0.04)$ cmol dm ${ }^{-3} ; \mathrm{Ca}-0.63( \pm 0.22) \mathrm{cmol} \mathrm{dm}^{-3}$ versus 1.66 $( \pm 0.34) \mathrm{cmol} \mathrm{dm}^{-3}$ and $\mathrm{Mg}-0.23( \pm 0.05) \mathrm{cmol} \mathrm{dm}^{-3}$ versus $0.82( \pm 0.14) \mathrm{cmol} \mathrm{dm}^{-3}$. Otherwise, the concentration of $\mathrm{Al}$ is high at the forest $\left(0.56( \pm 0.18) \mathrm{cmol} \mathrm{dm}^{-3}\right)$ and negligible at the pasture. Also, the soil is more acid at the forest than at the pasture, with the average $\mathrm{pH}\left(\mathrm{H}_{2} \mathrm{O}\right)$ equal to $4.19 \pm 0.21$ and $5.75 \pm 0.20$, respectively. The organic matter content is of the same order at both forest and pasture: $1.67( \pm 0.15) \%$ versus $1.97( \pm 0.16) \%$, but there are differences in the clay content (Table 1), which also alter $t$.

[13] The resulting soil moisture contents were also compared with the corresponding gravimetric determinations in soil samples collected about $2 \mathrm{~m}$ away from the FDRs, as presented in Table 3.

\section{Soil Thermal Properties}

[14] Temperature profiles in the soil may be obtained through the integration of the heat conduction equation,

$$
C \frac{\partial T}{\partial t}=\frac{\partial}{\partial z}\left(\lambda \frac{\partial T}{\partial z}\right)
$$

where $\mathrm{T}$ is temperature in ${ }^{\circ} \mathrm{C}, \mathrm{t}$ is time in $\mathrm{s}, \mathrm{z}$ the depth in $\mathrm{m}$, $\mathrm{C}$ the volumetric heat capacity of the soil $\left(\mathrm{J} \mathrm{m}^{-3} \mathrm{~K}^{-1}\right)$, and $\lambda$ is its apparent thermal conductivity in $\mathrm{W} \mathrm{m}^{-1} \mathrm{~K}^{-1}$. Also,

$$
\begin{aligned}
& C=\rho C_{b} \\
& \lambda=C \alpha
\end{aligned}
$$

where $\alpha$ is the apparent thermal diffusivity in $\mathrm{m}^{2} \mathrm{~s}^{-1}, \rho$ is the bulk density of the soil in $\mathrm{kg} \mathrm{m}^{-3}$ and $\mathrm{C}_{\mathrm{b}}$ is the bulk specific heat capacity in $\mathrm{J} \mathrm{kg}^{-1} \mathrm{~K}^{-1}$. However, these parameters vary with the composition, texture and moisture content of the soil. For soils with small organic matter contents, such as the ones in the present case $(1.74 \%$ to $2 \%$ in the depths considered, Table 1), their effects on $\mathrm{C}$ are negligible. Thus, as shown by Campbell [1985] and following de Vries [1966], it may be obtained from

$$
C=\frac{\rho}{\rho_{m}} C_{m}+\theta C_{w}
$$


where $\mathrm{C}_{\mathrm{m}}$ and $\mathrm{C}_{\mathrm{w}}$ are the specific heats of the mineral constituents of the soil and of water, respectively, $\rho_{\mathrm{m}}$ is the density of the mineral fraction and $\theta\left(\mathrm{m}^{3} \mathrm{~m}^{-3}\right)$ is the volumetric moisture content of the soil. In this work, the mineral constituents are considered as being quartz. Thus, $\rho_{\mathrm{m}}=2650 \mathrm{~kg} \mathrm{~m}^{-3}, \mathrm{C}_{\mathrm{m}}=2.13 \mathrm{MJ} \mathrm{m}^{-3} \mathrm{~K}^{-1}$ and $\mathrm{C}_{\mathrm{w}}=$ $4.18 \mathrm{MJ} \mathrm{m}^{-3} \mathrm{~K}^{-1}$.

[15] The apparent thermal diffusivity, which is considered to be constant for a uniform soil, can be determined by several methods using measurements of transient soil temperatures. These methods are based on either analytical or numerical solutions of the equation of heat conduction, and six of them were evaluated by Horton et al. [1983]. However, as actual soils are vertically nonuniform, with varying composition, texture and moisture content, more elaborate methods should be used [Lettau, 1954; van Wijk and Derksen, 1966; Nassar and Horton, 1989].

[16] Alternatively, the nonuniform soil may be divided into layers, each considered to be of uniform composition and structure, in which $\alpha$ and $\mathrm{C}$ are assumed constant. So, equation (3) becomes

$$
\frac{\partial T}{\partial t}=\alpha_{j}\left(\frac{\partial^{2} T}{\partial z^{2}}\right)
$$

where $\alpha_{j}=(\lambda / C)_{j}$, is the apparent thermal diffusivity of layer $\mathrm{j}$, limited by $\mathrm{z}_{\mathrm{j}-1}$ and $\mathrm{z}_{\mathrm{j}+1}, \mathrm{j}=1,2, \ldots \mathrm{m}$, the number of layers, not necessarily of equal thickness [Alvalá et al., 1996]. It should be noted that in this case there is no explicit dependence of the apparent thermal diffusivity on the soil moisture content.

[17] The apparent thermal diffusivity may be determined by the use of measured soil temperatures substituted into expressions obtained from analytical solutions of equation (7). This is the case for five of the methods shown by Horton et al. [1983] and by them referred as "periodic" methods; they require measured temperature time series in two soil levels, and no initial vertical profile. Otherwise, numerical solutions of equation (7), for measured initial plus upper and lower boundary conditions, may also be obtained with a succession of assumed values of $\alpha$, followed by the comparison of the computed temperature series with the measured ones, to find the value of $\alpha$ which minimizes the root mean squared (RMS) differences between the measured and the corresponding computed series inside the soil layer considered, which is the nonperiodic method named by Horton et al. [1983] as "numeric". It requires measured temporal temperature series in at least three soil levels, i.e., the upper and lower boundaries plus at least one intermediate series to verify the root mean square (RMS) adjustment. However, it allows for any initial and boundary conditions, as opposed to the periodic methods, which presuppose sinusoidal (or Fourier series) boundary conditions. This method is used in the present work, as described below, following the procedure shown by Alvalá et al. [1996]. Finally, an upper limit for the apparent thermal diffusivity, as function of the soil moisture content, is obtained through the linear superposition of the thermal diffusivities of the mineral, water and air volumetric of the soil layer fractions $\left(\alpha_{m}, \alpha_{w}\right.$ and $\alpha_{\text {air, }}$, respectively), that is

$$
\alpha_{j}=\frac{\rho}{\rho_{m}} \alpha_{m}+\theta \alpha_{w}+\left(1-\frac{\rho}{\rho_{m}}-\theta\right) \alpha_{\text {air }}
$$

where the mineral fraction is considered as quartz and the small organic contribution is neglected. Thus, with $\alpha_{m}=$ $4.13 \times 10^{-6} \mathrm{~m}^{2} \mathrm{~s}^{-1}, \alpha_{w}=0.14 \times 10^{-6} \mathrm{~m}^{2} \mathrm{~s}^{-1}$ and $\alpha_{\text {air }}=$ $20.83 \times 10^{-6} \mathrm{~m}^{2} \mathrm{~s}^{-1}$, this upper limit decreases from ca. $11.12 \times 10^{-6} \mathrm{~m}^{2} \mathrm{~s}^{-1}$ for no water content to $4.10 \times 10^{-6}$ $\mathrm{m}^{2} \mathrm{~s}^{-1}$ for the highest value measured at both sites $(\theta=0.34$ $\mathrm{m}^{3} \mathrm{~m}^{-3}$ ). The actual apparent soil thermal diffusivities are smaller, because the heat transport inside the soil is not uniform, presenting internal resistances due to its pores and their air-water content.

[18] In this work, the equation (7) was put in the form of nonequally spaced finite differences by means of a second order weighted scheme [Ralston and Wilf, 1964; Campbell, 1985]. The apparent thermal diffusivity, as detailed by Alvalá et al. [1996], was then obtained by successive iterations using the RMS minimizing procedure, for 24 hours LST periods. The boundary conditions used were the $0.10 \mathrm{~m}$ and $0.40 \mathrm{~m}$ measured soil temperature series, while the $0.20 \mathrm{~m}$ measured series were used for the RMS comparison with the computed temperatures at this level. The initial estimate of the apparent thermal diffusivity was determined by the amplitude periodic method [Horton et al., 1983], that is

$$
\alpha_{j}=\frac{\pi}{P} \frac{\left(z_{2}-z_{1}\right)}{\ln \left(A_{1} / A_{2}\right)}
$$

where $A_{1}$ and $A_{2}$ are the temperature amplitudes at depths $\mathrm{z}_{1}$ and $\mathrm{z}_{2}$, respectively, of the corresponding transient temperature records, and $\mathrm{P}$ is the cyclic time period, in this case 24 hours. Usually the values thus found were higher than the ones which minimized the above mentioned RMS. Finally, the apparent soil heat conductivity was computed through equation (5).

\section{Results}

[19] The incident solar energy flux at the ground surface $(\mathrm{K} \downarrow)$ is the primary source for all other components of the radiation balance, while the net radiation $\left(R_{n}\right)$ is partitioned into sensible and latent heats, soil heat flux (G), energy storage in the above ground biomass and liquid water cover, plus other minor terms. These variables affect both the soil and the air temperature and moisture content profiles. Thus, to characterize the wet February and dry August periods, the monthly statistics of measured daily accumulated energy fluxes at the forest and pasture sites studied are shown on Tables 4 and 5. During the wet period, at both sites, the average daily accumulated $\mathrm{K} \downarrow$, which is inversely proportional to the density of the cloud cover, was smaller than during the dry period, indicating a denser cloud cover during the wet period. On the other hand, during the wet period, the daylight cloud cover was on the average heavier and with more variance at the forest, showed by an average daily accumulated $\mathrm{K} \downarrow(\mathrm{AK} \downarrow)$ equal to $16.8( \pm 4.75) \mathrm{MJ} \mathrm{m}^{-2}$ 
Table 4. Monthly Statistics of Measured Daily Accumulated Energy Fluxes at the Forest and the Pasture During the Wet Period (DOYs 32-59)

\begin{tabular}{|c|c|c|c|c|c|c|}
\hline & $\begin{array}{c}\mathrm{AK} \downarrow \\
\mathrm{MJ} \mathrm{m}^{-2}\end{array}$ & $\mathrm{a}$ & $\begin{array}{c}\mathrm{AR}_{\mathrm{n}}, \\
\mathrm{MJ} \mathrm{m}^{-2}\end{array}$ & $\begin{array}{c}\mathrm{AG}, \\
\mathrm{MJ} \mathrm{m}^{-2}\end{array}$ & $\mathrm{AR}_{\mathrm{n}} / \mathrm{AK} \downarrow$ & $\mathrm{AG} / \mathrm{AR}_{\mathrm{n}}$ \\
\hline \multicolumn{7}{|c|}{ Forest, February 1999} \\
\hline Average & 16.80 & n.a. & 12.63 & -0.18 & 0.72 & -0.02 \\
\hline STD & 4.75 & n.a. & 3.53 & 0.16 & 0.08 & 0.01 \\
\hline Max & 24.41 & n.a. & 21.79 & 0.20 & 1.04 & 0.01 \\
\hline Min & 6.45 & n.a. & 6.69 & -0.52 & 0.65 & -0.05 \\
\hline \multicolumn{7}{|c|}{ Pasture, February 1999} \\
\hline Average & 17.37 & $0.20^{\mathrm{a}}$ & 11.27 & 0.04 & 0.65 & -0.01 \\
\hline STD & 3.71 & 0.003 & 2.42 & 0.37 & 0.04 & 0.04 \\
\hline Max & 24.04 & 0.20 & 15.37 & 0.99 & 0.73 & 0.05 \\
\hline Min & 8.54 & 0.19 & 5.70 & -0.76 & 0.60 & -0.11 \\
\hline
\end{tabular}

STD, standard deviation; a, albedo; n.a., not available.

ancomplete series.

(Table 4, upper part), versus $17.37( \pm 3.71) \mathrm{MJ} \mathrm{m}^{-2}$ (Table 4 , lower part) at the pasture, a situation that was reversed during the dry period, with $18.84( \pm 2.06) \mathrm{MJ} \mathrm{m}^{-2}$ (Table 5, upper part) versus $17.83( \pm 3.71) \mathrm{MJ} \mathrm{m}^{-2}$ (Table 5 , lower part). For the average daily accumulated $R_{n}\left(A R_{n}\right)$ the values were $12.63( \pm 3.53) \mathrm{MJ} \mathrm{m}^{-2}$ (Table 4 , upper part) at the forest and $11.27( \pm 2.42) \mathrm{MJ} \mathrm{m}^{-2}$ (Table 4, lower part) at the pasture during the wet period, followed by 11.01 $( \pm 1.67) \mathrm{MJ} \mathrm{m}^{-2}$ (Table 5, upper part) and $7.74( \pm 0.97) \mathrm{MJ}$ $\mathrm{m}^{-2}$ (Table 5, lower part), respectively, during the dry period, that is, a pattern identical to the one for $\mathrm{K} \downarrow$, with the exception of the smaller variance at the pasture during the dry period. The monthly average of the daily quotients $\mathrm{AR}_{\mathrm{n}} / \mathrm{AK} \downarrow$ was higher during the wet period at both sites, equaling $0.72( \pm 0.08)$ at the forest and $0.65( \pm 0.04)$ at the pasture (Table 4$)$, versus respectively $0.58( \pm 0.04)$ and 0.44 $( \pm 0.05)$ during the dry period (Table 5$)$, with values during the same period always higher at the forest. The daily accumulated values of $\mathrm{G}(\mathrm{AG})$, with maxima (daily heat accumulation in the soil causing its temperature to rise) of up to $3 \%$ of $\mathrm{AR}_{\mathrm{n}}$ at the forest (dry period, see Table 5, upper part) and $18 \%$ at the pasture (dry period, see Table 5, lower part), and the respective minima (daily heat depletion in the soil) of up to $5 \%$ (wet period, see Table 4 , upper part) and $11 \%$ (wet period, see Table 4, lower part), respectively, show the importance of the soil heat flux. The lower values at the forest are consequences of a greater energy storage in its canopy, despite its consistently lower albedo, that is, less solar energy reflection. This also causes a consistently greater variance of the monthly average $\mathrm{AG}$ at the pasture (wet period: $0.37 \mathrm{MJ} \mathrm{m}^{-2}$, Table 4, lower part; dry period: $0.37 \mathrm{MJ} \mathrm{m}^{-2}$, Table 5, lower part) than at the forest (wet period: $0.16 \mathrm{MJ} \mathrm{m}^{-2}$, Table 4, upper part; dry period: 0.31 MJ $\mathrm{m}^{-2}$, Table 5, upper part), and consequently, greater daily soil temperature ranges, which influence the soil moisture content, that is, its evaporation process.

[20] Next, the detailed results concerning the soil temperature, heat flux, moisture content, and thermal properties are presented.

\subsection{Soil Temperature and Heat Flux}

[21] During the wet season month of February, the soil temperature at the depth of $0.10 \mathrm{~m}$ at the forest (Figure 1c) presented an overall $10 \mathrm{~min}$ sampled average of 24.78 $( \pm 0.37)^{\circ} \mathrm{C}$, an absolute maximum of $25.85^{\circ} \mathrm{C}$ and an absolute minimum of $24.04^{\circ} \mathrm{C}$ (Table 6), while the corresponding values at the pasture (Figure 2c) were $26.59( \pm 1.49)^{\circ} \mathrm{C}$, $31.09^{\circ} \mathrm{C}$ and $23.67^{\circ} \mathrm{C}$ (Table 6). Thus, except for the $0.10 \mathrm{~m}$ minimum, the values at the forest were smaller than at the pasture, including the range between corresponding maxima and minima. Without the exception mentioned, this was also the behavior at the 0.20 and $0.40 \mathrm{~m}$ depths, with

Table 5. Monthly Statistics of Measured Daily Accumulated Energy Fluxes at the Forest and the Pasture During the Dry Period (DOYs 213-243)

\begin{tabular}{|c|c|c|c|c|c|c|}
\hline & $\begin{array}{c}\mathrm{AK} \downarrow \\
\mathrm{MJ} \\
\mathrm{m}^{-2}\end{array}$ & a & $\begin{array}{c}\mathrm{AR}_{\mathrm{n}}, \mathrm{MJ} \\
\mathrm{m}^{-2}\end{array}$ & $\begin{array}{c}\mathrm{AG}, \\
\mathrm{MJ} \mathrm{m}^{-2}\end{array}$ & $\mathrm{AR}_{\mathrm{n}} / \mathrm{AK} \downarrow$ & $\mathrm{AG} / \mathrm{AR}_{\mathrm{n}}$ \\
\hline \multicolumn{7}{|c|}{ Forest, August 1999} \\
\hline Average & 18.84 & $0.15^{\mathrm{a}}$ & 11.01 & -0.03 & 0.58 & 0.00 \\
\hline STD & 2.06 & 0.01 & 1.67 & 0.31 & 0.04 & 0.03 \\
\hline Max & 21.65 & 0.17 & 14.99 & 0.28 & 0.71 & 0.03 \\
\hline Min & 15.25 & 0.14 & 8.20 & -1.12 & 0.51 & -0.10 \\
\hline \multicolumn{7}{|c|}{ Pasture, August 1999} \\
\hline Average & 17.83 & 0.24 & 7.74 & 0.72 & 0.44 & 0.09 \\
\hline STD & 3.71 & 0.01 & 0.97 & 0.37 & 0.05 & 0.14 \\
\hline $\operatorname{Max}$ & 20.59 & 0.26 & 9.53 & 1.69 & 0.54 & 0.18 \\
\hline Min & 13.42 & 0.21 & 5.78 & -2.89 & 0.40 & -0.41 \\
\hline
\end{tabular}

STD, standard deviation; a, albedo.

${ }^{\mathrm{a}}$ Incomplete series. 


\section{Forest - February 1999}

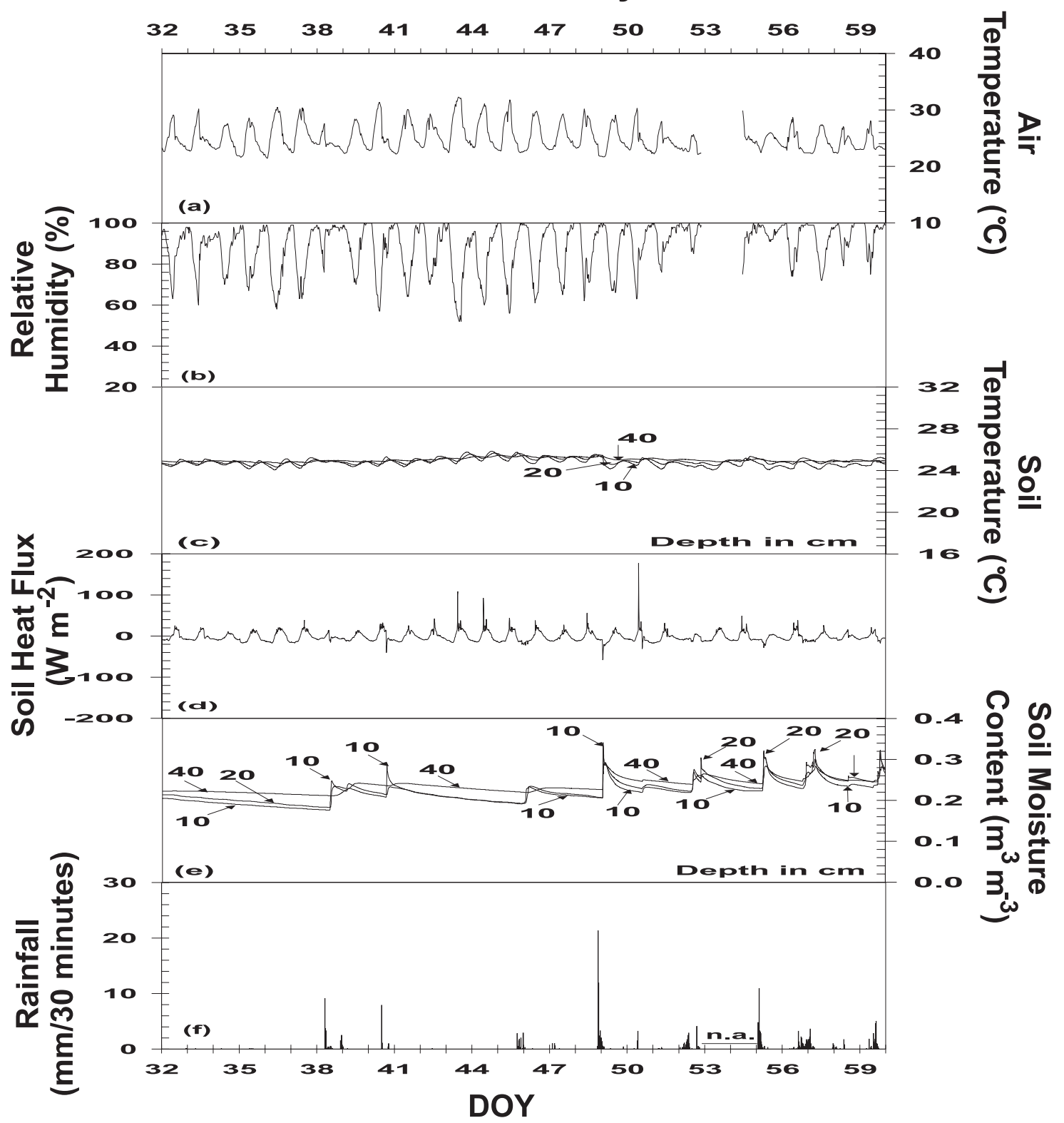

Figure 1. Daily variation of air temperature, relative humidity, soil heat flux, soil volumetric water content, soil temperature, and rainfall measured at the forest, February 1999.

smaller ranges between the extrema at both sites, as evidenced by their respective monthly standard deviations (Figures $1 \mathrm{c}$ and $2 \mathrm{c}$ and Table 6). During the dry season month of August (Figures $3 \mathrm{c}$ and $4 \mathrm{c}$ and Table 7), the behavior was similar to the one of the wet season, with the evident temperature decrease, due to the passage of a strong cold front sensed in both sites. Incidentally, the sudden changes of the instantaneous derivatives (i.e., nonsmoothness) in the daily cycling of most of the signals are due to the passage of clouds, with or without rainfall; the air temperature and the relative humidity show strong responses to the passage of clouds or rainfall, as can be seen in Figures $1 \mathrm{a}$ and $1 \mathrm{~b}$ and $2 \mathrm{a}$ and $2 \mathrm{~b}$.
[22] The soil heat flux during February, at both sites, presented strong influence of the passage of clouds and rainfall, mixed with some direct sunshine, which caused sunflecks in the forest, where the leaf area index averaged $4.9 \mathrm{~m}^{2} \mathrm{~m}^{-2}$. So, the passage of clouds brought nonsmoothness to this signal, while the sunflecks caused positive spikes and rainfall negative ones, as can be seen on Figures $1 \mathrm{~d}$ and $2 \mathrm{~d}$. The $10 \mathrm{~min}$ averages sampled soil heat flux range at the forest was from -16.32 to $21.04 \mathrm{~W} \mathrm{~m}^{-2}$ (Figure 1d), while at the pasture it ranged from -32.03 to $167.10 \mathrm{~W} \mathrm{~m}^{-2}$ (Figure 2d); in both cases, occasional spikes explained next, were excluded. Their monthly averages, including the spikes, were $-2.04( \pm 11.65) \mathrm{W} \mathrm{m}^{-2}$ at the 
ALVALA ET AL.: INTRADIURNAL AND SEASONAL VARIABILITY IN RONDÔNIA LBA $\quad \mathbf{1 0}$ - 7

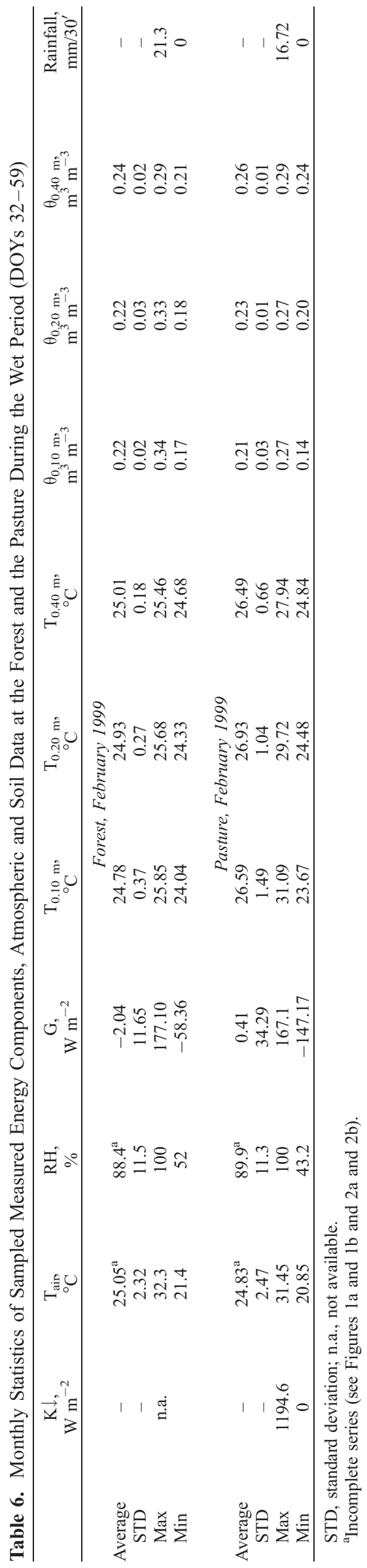




\section{Pasture - February 1999}

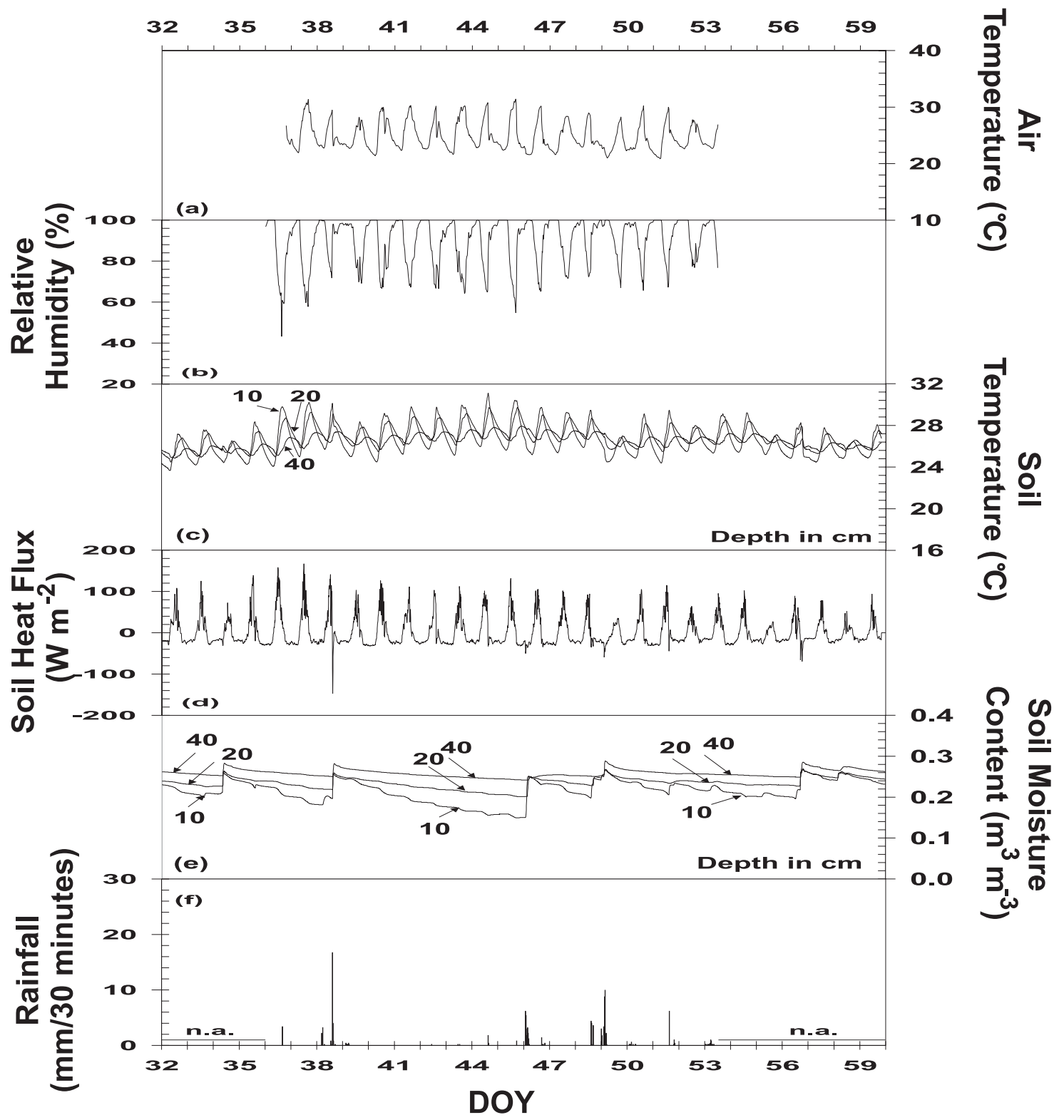

Figure 2. Same as Figure 1 at the pasture, February 1999.

forest (Table 6, upper part) and $0.41( \pm 34.29) \mathrm{W} \mathrm{m}^{-2}$ at the pasture (Table 6, lower part). At the forest, the spikes associated with sunflecks reached up to $177.10 \mathrm{~W} \mathrm{~m}^{-2}$ (Table 6, upper part), while rain episodes caused spikes down to $-58.36 \mathrm{~W} \mathrm{~m}^{-2}$ at the forest (Figure 1d and Table 6 , upper part), and $-147.17 \mathrm{~W} \mathrm{~m}^{-2}$ at the pasture (Figure 2d and Table 6, lower part). The last ones are clear signatures of concentrated rainfalls (Figures $1 \mathrm{f}$ and 2f). They may be used to verify the occurrence of rainfalls in the absence of actual measurements. This was eventually the case during the experiment, such as on DOY 56 at the pasture, also evidenced by the soil moisture content change shown on Figure 2e. The daily accumulated soil heat flux values reached maxima (which cause soil temperature rises) of up to $3 \%$ of the daily accumulated net radiation at the forest (Table 5, upper part), and up to $18 \%$ at the pasture (Table 5, lower part), while the respective minima (which cause soil heat depletion) during wet period were respectively $10 \%$ and $41 \%$. These extrema, due to its smaller vegetation cover, are greater at the pasture, determine the soil temperature ranges. Further, it is interesting to note that on DOY 38 a squall line, originated over the Atlantic Ocean and combined with a cold front, brought rainfalls of 24.40 $\mathrm{mm}$ at the forest and $28.2 \mathrm{~mm}$ at the pasture. From DOY 37 to 38 the maximum air temperature decreased from $30.40^{\circ} \mathrm{C}$ to $24.20^{\circ} \mathrm{C}$ at the forest (Figure 1a), and from $31.39^{\circ} \mathrm{C}$ to $29.48^{\circ} \mathrm{C}$ at the pasture (Figure 2a). The corresponding decreases of the maximum soil temperatures at the forest 


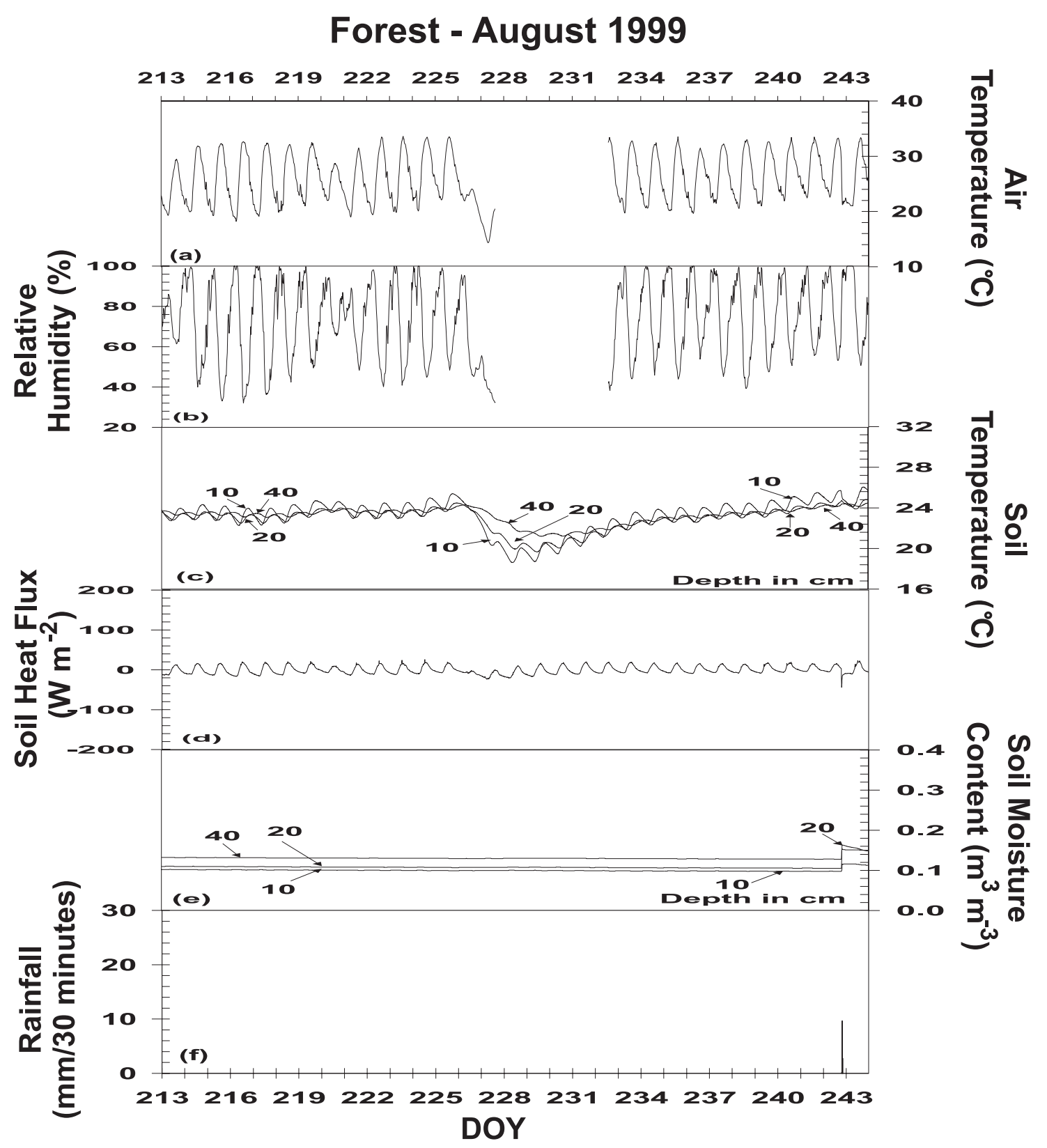

Figure 3. Same as Figure 1 at the forest, August 1999.

occurred at the same time; however, at the pasture they were delayed by one day. Notwithstanding, the soil heat flux presented a spike of $-147.17 \mathrm{~W} \mathrm{~m}^{-2}$ at the pasture, and none at the forest. On the other hand, the total rainfalls of $48.3 \mathrm{~mm}$ at the forest and $42.99 \mathrm{~mm}$ at the pasture, which occurred on DOYs 48 and 49, respectively, caused a strong decrease of the maxima of the soil temperatures, but not on the maximum air temperatures; also, the soil heat flux presented spikes of $-58.36 \mathrm{~W} \mathrm{~m}^{-2}$ at the forest and of $-59.35 \mathrm{~W} \mathrm{~m}^{-2}$ at the pasture.

[23] During the dry month of August, at both sites (Figures $3 \mathrm{c}$ and $4 \mathrm{c}$ ), the soil temperatures presented larger daily amplitudes than the ones for the wet month, due to less cloudiness. Concerning to the soil heat flux, it is a nonnegligible component of the daily energy balance at the pasture. A mild cold front occurred on DOY 220, with small temperature decreases and no rain associated. However, after sunset on DOY 225, a strong cold front reached the region, caused by a cold mass that affected most of Brazil [INPE, 1999]. Its main measured temperature characteristics are presented for both sites on Figures 5 and 6 . At the forest there was a sole 12.59 $\mathrm{mm}$ rainfall on DOY 242 (August 30), after a 60 days long dry-spell, causing a $-44.35 \mathrm{~W} \mathrm{~m}^{-2}$ soil heat flux spike (Figures $3 \mathrm{f}$ and $3 \mathrm{~d}$ ). At the pasture, two rainfalls occurred: $11.54 \mathrm{~mm}$ on DOY 225 (August 13, after a 37 days dry-spell) and $50.00 \mathrm{~mm}$ on DOY 240 (August 28), respectively with soil heat flux spikes of $-123.7 \mathrm{~W} \mathrm{~m}^{-2}$ 


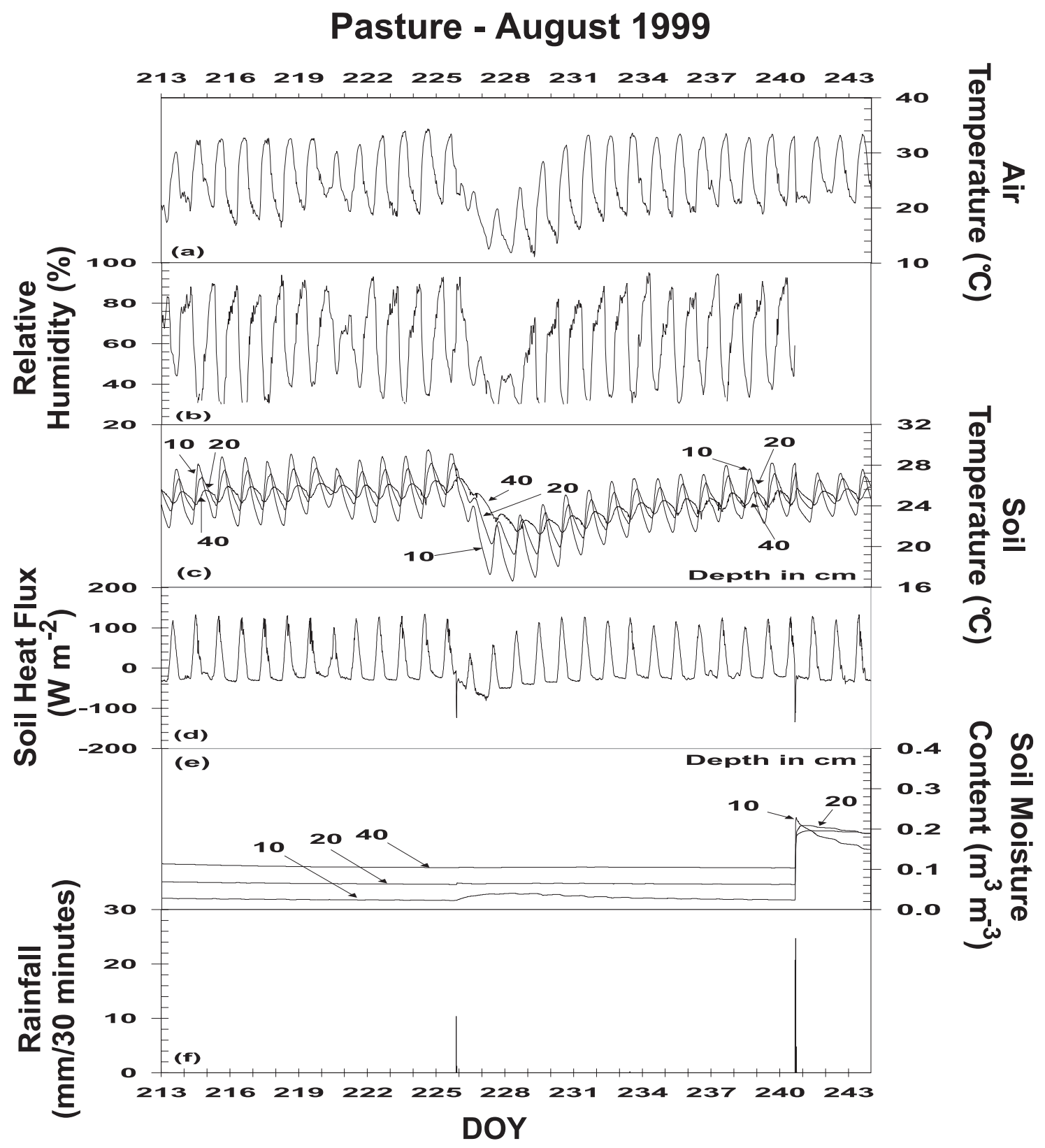

Figure 4. Same as Figure 1 at the pasture, August 1999.

and $-127.57 \mathrm{~W} \mathrm{~m} \mathrm{~m}^{-2}$ (Figures $4 \mathrm{f}$ and $4 \mathrm{~d}$ ). Concerning cold fronts, it should be noted that outside the periods presented above, on DOYs 187 (July 6), 262 (September 19) and 276 (October 3) milder ones reached the region.

\subsection{Soil Moisture Content}

[24] The soil moisture content $(\theta)$, at the depths of 0.10 , 0.20 , and $0.40 \mathrm{~m}$, increased after a rainfall event and immediately started to decrease until the next rain, indicating that water in these sandy soils rapidly drains toward deeper layers during rainfall events, as it is shown on Figures $1 \mathrm{e}$ and $2 \mathrm{e}$ for both sites during the wet month of February. Notice that the $\theta$ normally increases with depth, except immediately after most rainfall events at the forest, such as those of DOYs 38, 40, 45, 48 and thereafter, when the more superficial layer was wetter. However, at the pasture this inversion seldom occurred. The rates of drying were higher nearer to the surface at both sites. Also, on nonrainy days, these rates were higher during the daylight hours and decreased at night, as may be seen after DOY 38 (February 7) at the pasture (Figure 2e); this behavior, which is less intense at the forest, reflects the presence or not of sunlight and its intensity. The drying gradients are lower at the forest than at the pasture site, which can be better seen during August and September at both sites, such after the rainfalls of $12.6 \mathrm{~mm}$ on DOY 242 (August 30) at the forest and $50.36 \mathrm{~mm}$ on DOY 240 (August 28) at the pasture (Figures 3e, 4e, 7, and 8). 
ALVALA ET AL.: INTRADIURNAL AND SEASONAL VARIABILITY IN RONDÔNIA LBA 10 - 11

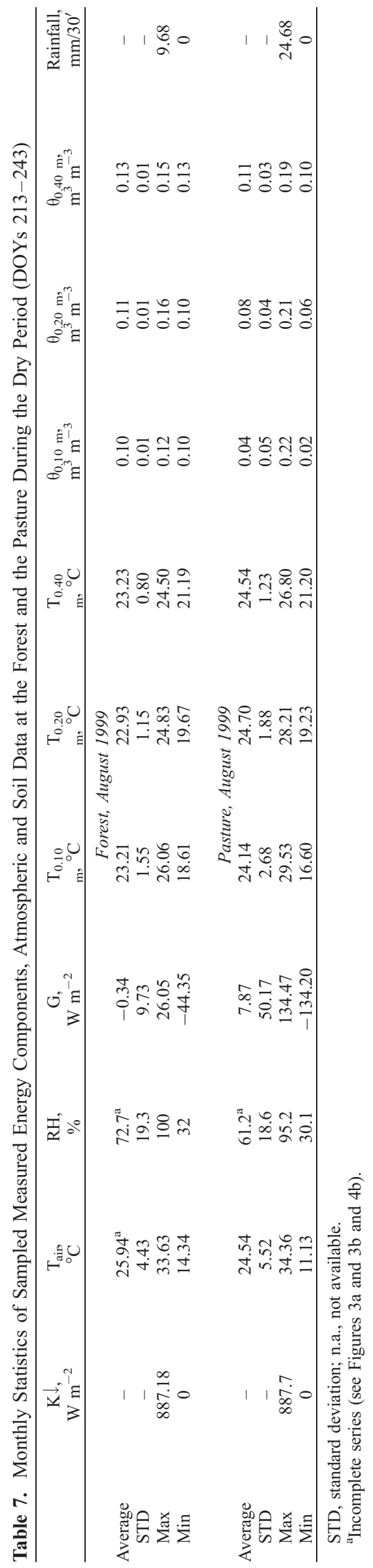




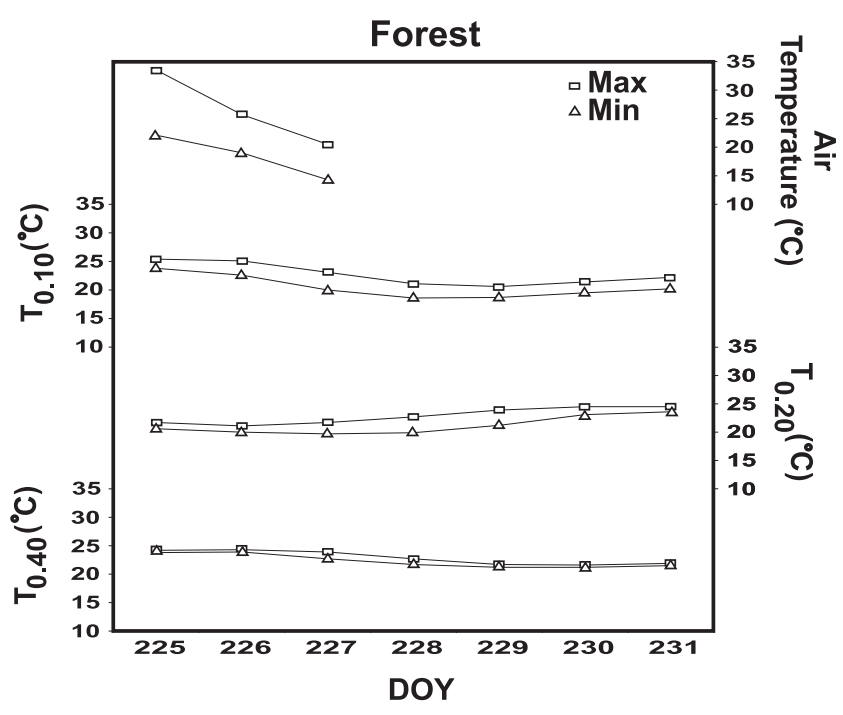

Figure 5. Temperature extrema for the DOY 225 cold front at the forest.

[25] The maximum soil moisture content at the forest was $0.34 \mathrm{~m}^{3} \mathrm{~m}^{-3}$ at the depth of $0.10 \mathrm{~m}$, and $0.29 \mathrm{~m}^{3} \mathrm{~m}^{-3}$ at $0.40 \mathrm{~m}$, both on DOY 49 (February 18, Figure 1e and Table 6 , upper part). At the pasture, these maxima were respectively 0.27 and $0.29 \mathrm{~m}^{3} \mathrm{~m}^{-3}$, both on DOY 49 (February 18, Figure 2e and Table 6, lower part). These were the 1999 annual maxima which, together with all others, were caused by rainfalls.

[26] So, at the forest, after $34.39 \mathrm{~mm}$ of rainfall between DOYs 123 (May 3) and 170 (June 19) and a precipitation of $28.80 \mathrm{~mm}$ from DOYs 171 to 183 (June 20 to July 2), a dry-spell of 37 days occurred up to DOY 242 (August 30, Figure 3f), when a $12.6 \mathrm{~mm}$ rainfall occurred. It was then followed by an accumulated rain of $30 \mathrm{~mm}$ on DOY 258 (September 15, Figure 7). This last day may be considered the beginning of the new wet season at the forest, with initially sparse but intense rains above $30 \mathrm{~mm}$ each (see Figure 7). The minima of $\theta$ at the forest were $0.10 \mathrm{~m}^{3} \mathrm{~m}^{-3}$ at $0.10 \mathrm{~m}$ and $0.13 \mathrm{~m}^{3} \mathrm{~m}^{-3}$ at $0.40 \mathrm{~m}$, both on DOY 242 (August 30, Figure 3f and Table 7, upper part).

[27] At the pasture, after rainfalls totaling $4.18 \mathrm{~mm}$ between DOYs 134 (May 14) and 173 (June 23), followed a rainfall of $44.97 \mathrm{~mm}$ on DOY 174 (June 24) plus a total of $13.13 \mathrm{~mm}$ precipitation from DOYs 175 to 184 (June 25 to July 3); then, it did not rain until DOY 254 (September 11, Figure 8), except for the DOY 225 (August 13, with $12.4 \mathrm{~mm}$ and a small increase of the $\theta$ only at the depth of $0.10 \mathrm{~m}$, Figure $4 \mathrm{e}$ ) and the DOY 240 (August 28, with $50 \mathrm{~mm}$ and a steep increase of the $\theta$ at all depths, Figure 4e). Thereafter, actually on DOY 262 (September 19, Figure 8), started the new rainy season, with immediate increase of the $\theta$ at the pasture (Figure 8). The minima of $\theta$ were $0.02 \mathrm{~m}^{3} \mathrm{~m}^{-3}$ at $0.10 \mathrm{~m}$ and $0.10 \mathrm{~m}^{3} \mathrm{~m}^{-3}$ at $0.40 \mathrm{~m}$, both on DOY 240 (August 28, Figure 4e and Table 7, lower part).
[28] During the transition from dry to wet season at the pasture (Figure 8), when the $\theta$ at $0.40 \mathrm{~m}$ increased from $0.12 \mathrm{~m}^{3} \mathrm{~m}^{-3}$ on DOY 262 (September 19) to $0.24 \mathrm{~m}^{3}$ $\mathrm{m}^{-3}$ on DOY 268 (September 25), the soil was wetter at the 0.10 and $0.20 \mathrm{~m}$ depths; thereafter, the normal pattern of increasing wetness with depth was reestablished. At the forest site (Figure 7), there was no inversion of patterns at the beginning of the new wet season, when on DOY 258 (September 15) the $\theta$ at $0.40 \mathrm{~m}$ started to increase from $0.13 \mathrm{~m}^{3} \mathrm{~m}^{-3}$ to $0.25 \mathrm{~m}^{3} \mathrm{~m}^{-3}$ on DOY 262 (September 19), in which the response to a $73.01 \mathrm{~mm}$ of accumulated rainfall occurred. The $\theta$ was lower at the forest than at the pasture site during the wet season, while the opposite occurred during the dry months. Finally, for both sites, as shown on Figure 9, a unique linear relation between the measured daily averages of the $\theta$ at $0.20 \mathrm{~m}$ and the accumulated moisture content in the $0.10-0.40 \mathrm{~m}$ soil layer was determined, which shows a strong similarity between the soils at both sites in terms of water retention.

\subsection{Soil Thermal Properties}

[29] The computed apparent daily average volumetric soil heat capacities, $\mathrm{C}$, for the $0.10-0.40 \mathrm{~m}$ soil layers studied, which are linearly dependent on $\theta$ (equation (6)), are presented on Figures 10, 11, 12, and 13 for both periods and sites, jointly with the daily rainfalls, the average $\theta$ for the $0.10-0.40 \mathrm{~m}$ soil layer $\left(\theta_{0.10-0.40}\right)$, the computed apparent soil thermal diffusivities $(\alpha)$ and conductivities $(\lambda)$. The $\mathrm{C}$ values are lower at the forest than at the pasture site during the wet February period, a situation that is reversed during the dry August period, as a consequence of the moisture condition of the soil. Their monthly statistics are shown on Table 8 , with averages for the wet period equal to $2.19( \pm 0.09) \mathrm{MJ} \mathrm{m}^{-3} \mathrm{~K}^{-1}$ at the forest and 2.23 $( \pm 0.05) \mathrm{MJ} \mathrm{m}^{-3} \mathrm{~K}^{-1}$ at the pasture (Table 8 , upper part). For the dry period these values were, respectively, 1.72

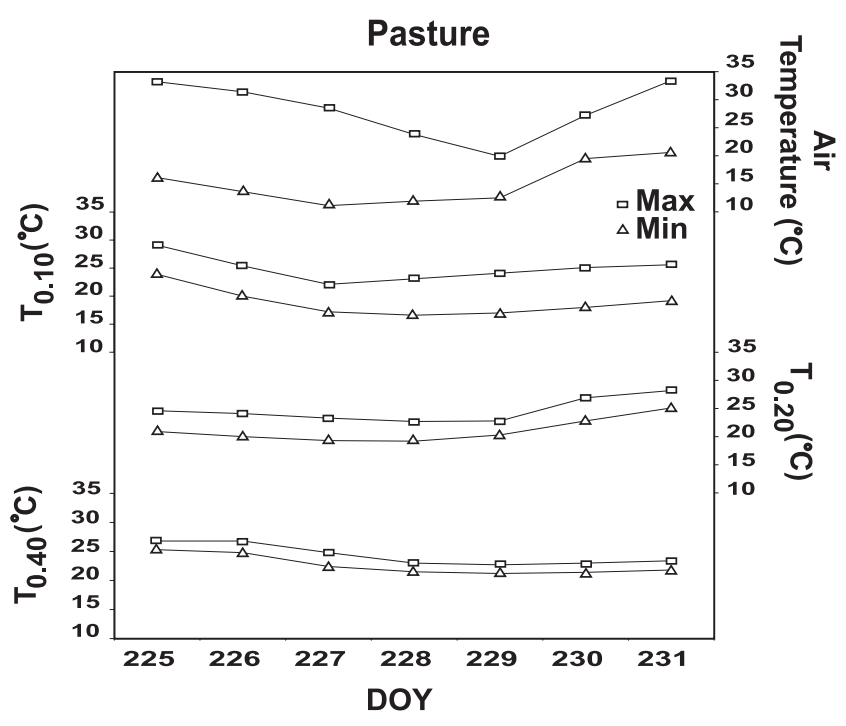

Figure 6. Same as Figure 5 at the pasture. 


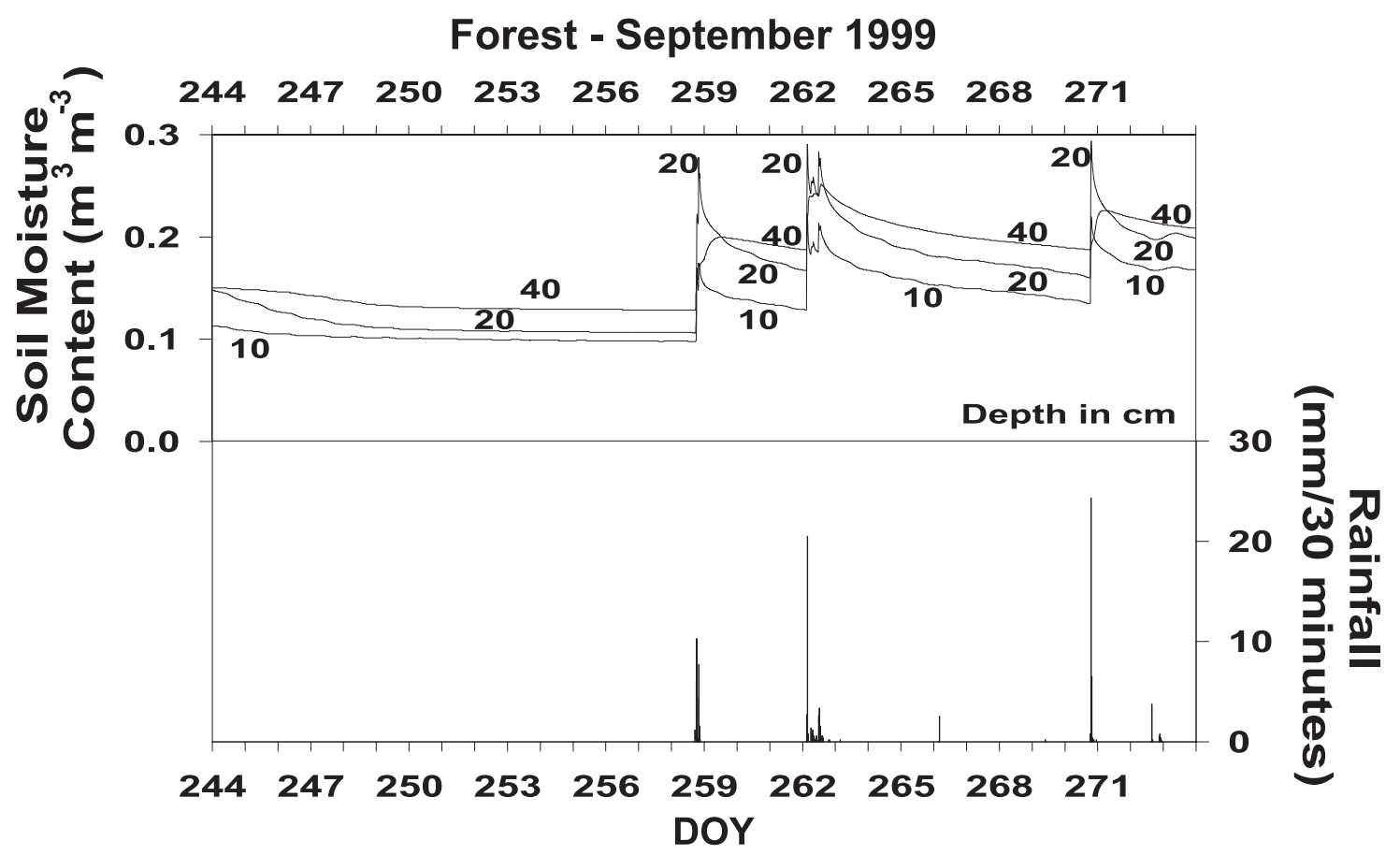

Figure 7. Soil moisture content and rainfall at the forest, September 1999.

$( \pm 0.02) \mathrm{MJ} \mathrm{m}^{-3} \mathrm{~K}^{-1}$ and $1.59( \pm 0.15) \mathrm{MJ} \mathrm{m}^{-3} \mathrm{~K}^{-1}$ (Table 8 , lower part).

[30] The computed apparent daily soil thermal diffusivities $(\alpha)$ and the corresponding bias and RMS deviations between the measured and computed soil temperatures at the depths of $0.20 \mathrm{~m}$, for each day at both sites and periods, are shown on Figures 10, 11, 12, and 13. Table 8 presents the monthly statistics for $\alpha$, while Table 9 shows

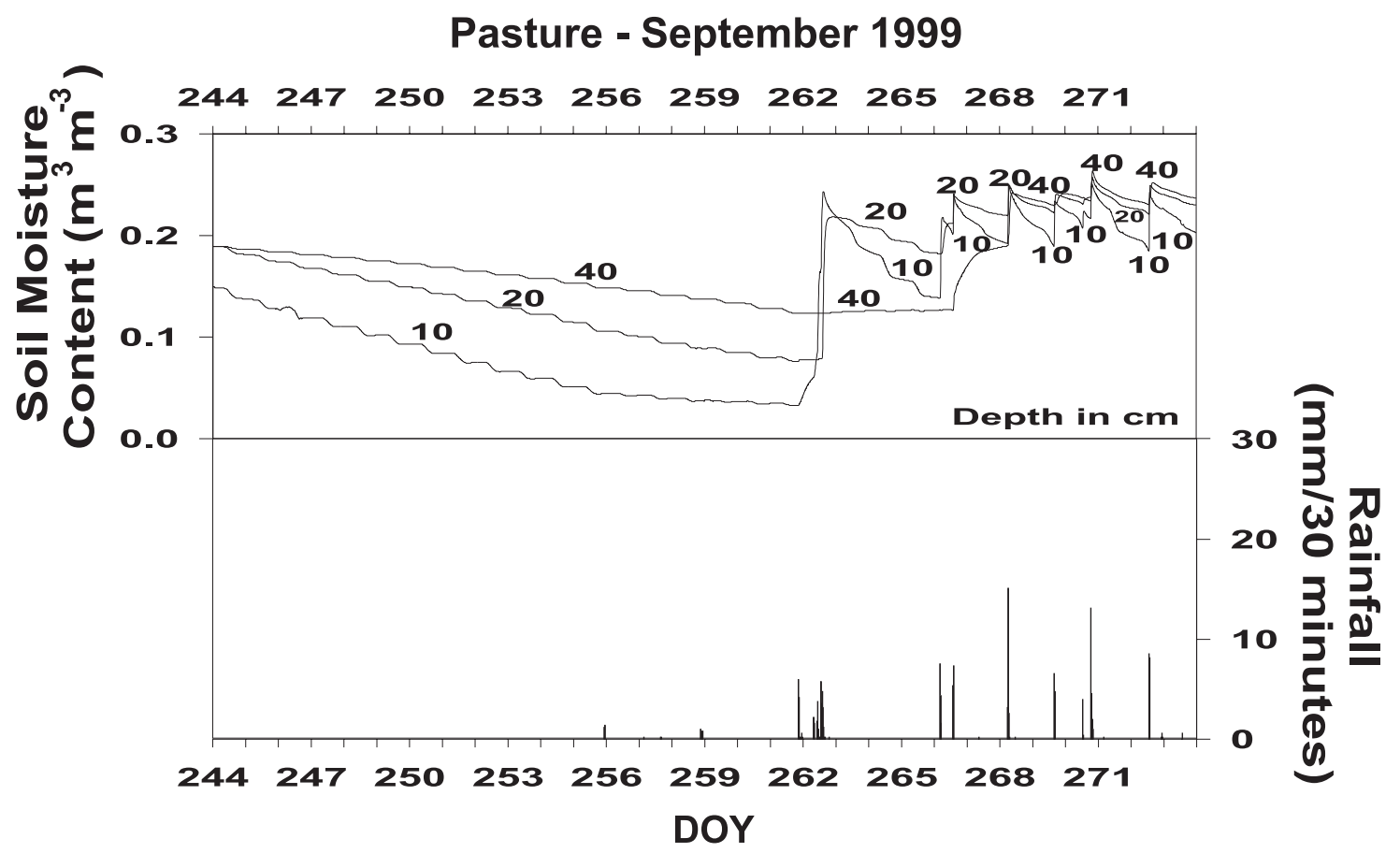

Figure 8. Same as Figure 7 at the pasture, September 1999. 

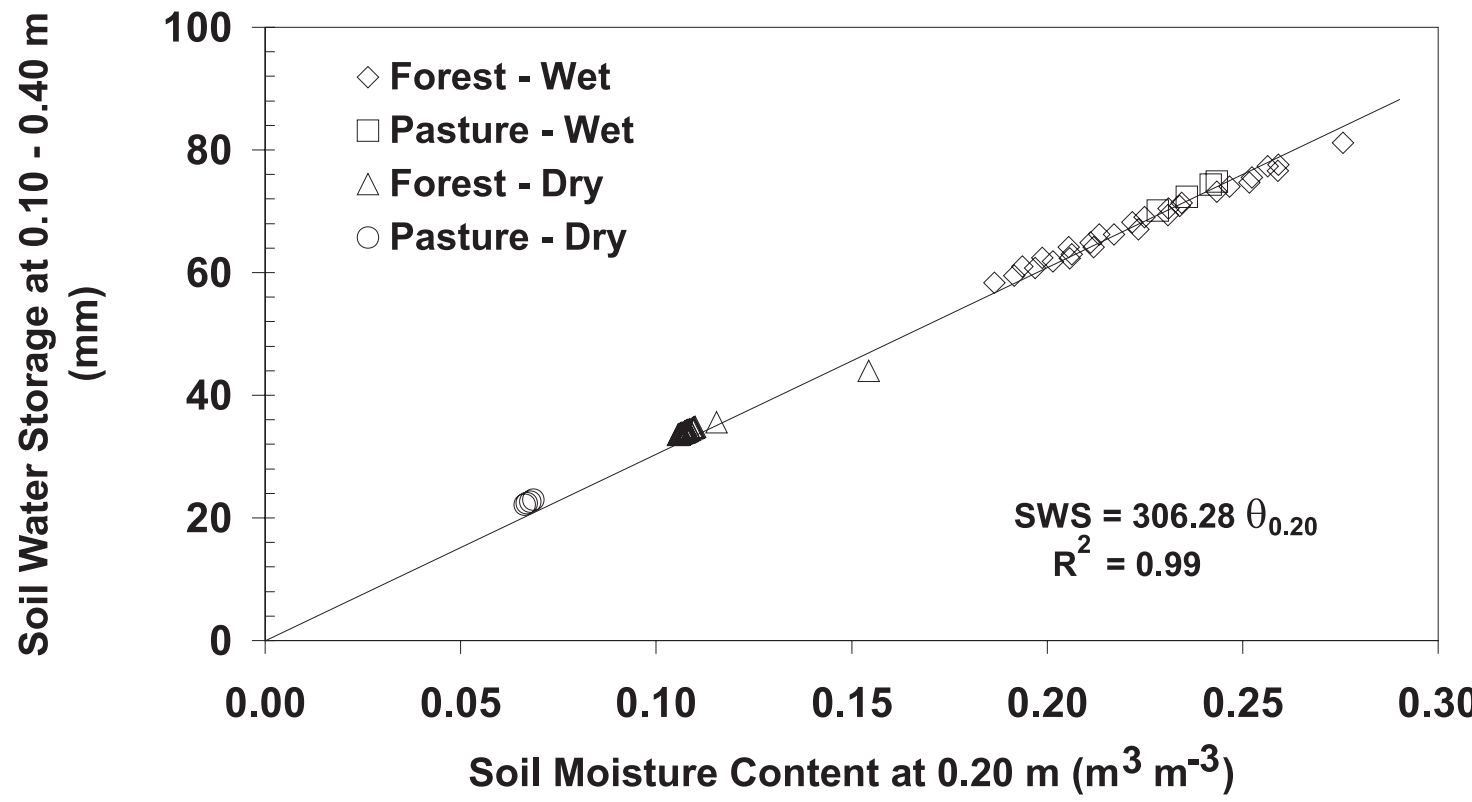

Figure 9. Soil moisture content at the $0.20 \mathrm{~m}$ depth versus soil storage in the $0.10-0.40 \mathrm{~m}$ layer.

the monthly statistics of the bias and RMS mentioned. The monthly averages of $\alpha$ for the wet period (Table 8 , upper part) were $1.08( \pm 0.44) \times 10^{-6} \mathrm{~m}^{2} \mathrm{~s}^{-1}$ for the forest and $1.34 \pm 0.37) \times 10^{-6} \mathrm{~m}^{2} \mathrm{~s}^{-1}$ for the pasture, while for the dry period (Table 8 , lower part) these values were, respectively, $0.55( \pm 0.33) \times 10^{-6} \mathrm{~m}^{2} \mathrm{~s}^{-1}$ and 1.16 $( \pm 0.14) \times 10^{-6} \mathrm{~m}^{2} \mathrm{~s}^{-1}$. All these results obtained for the apparent soil thermal diffusivities, as expected, are lower than the values predicted by equation (8), q. v. Each daily value of these diffusivities was used to compute the temperatures in the $0.10-0.40 \mathrm{~m}$ soil layer for the respective day, at both sites and periods. The quality of the adjustment depended on the site and the period, as well the particular daily situation, such as clear or cloudy, with or without rain, as well as the presence or not of a cold front. The statistics of the comparison between the computed and measured temperatures at the $0.20 \mathrm{~m}$ depths are shown on Table 9, presenting monthly average RMS between $0.08^{\circ} \mathrm{C}$ (forest, wet) and $0.33^{\circ} \mathrm{C}$ (pasture, wet), always with standard deviations not greater than $0.07^{\circ} \mathrm{C}$. The computed temperatures at the $0.20 \mathrm{~m}$ depths underestimated the measured ones in all periods and sites (positive biases), except during the dry at the forest (negative bias). The absolute monthly average biases varied between $0.03^{\circ} \mathrm{C}$ (forest, wet) and $0.30^{\circ} \mathrm{C}$ (pasture, wet), with standard deviations not greater than $0.08^{\circ} \mathrm{C}$. These results indicate, in general, good adjustments. Figure 14 presents some typical examples, with the smaller inserts depicting the three temperature series $(0.10 \mathrm{~m}, 0.20 \mathrm{~m}$ and $0.40 \mathrm{~m})$ measured during the day considered. However, for some days, such as the ones around DOY 55 at both sites (Figures 10d and 11d), the computed diffusivities vary strongly for reasons not yet determined, perhaps due to the presence or proximity of rain and the cloudiness associated. Also, no satisfactory reason was found to explain the fluctuations of $\alpha$ during the dry month of August at the forest (Figure 10d); but the relatively low values of $\alpha$ may be due to higher clay contents at the 0.20 and $0.40 \mathrm{~m}$ depths (Table 1), which is a nonhomogeneity that indicates the need of a finer vertical resolution in future studies.

[31] To show the dependence of $\alpha$ on $\theta_{0.10-0.40}$, all $\alpha$ values for the nonrainy days during the wet and dry periods considered, plus a selection from other days without rain over the year are presented on Figure 15. This choice avoided the influence of the steep temporal gradients of $\theta_{0.10-0.40}$ caused by rainfalls. Due to their spread, these data do not show a clear functional interdependence, even after excluding the set located around $\theta_{0.10-0.40}=0.11 \mathrm{~m}^{3} \mathrm{~m}^{-3}$ (the dry period forest values above mentioned). Notwithstanding, there seems to be a tendency for the diffusivities to be lower at the lowest and highest values of $\theta_{0.10-0.40}$, which is consistent with the occurrence of a maximum diffusivity occurring at intermediate soil moisture contents [Wierenga et al., 1969].

[32] The average computed apparent daily soil heat conductivities $(\lambda)$, obtained through equation (5), during the wet season (Table 8, upper part) were equal to $2.26( \pm 0.53)$ $\mathrm{W} \mathrm{m}{ }^{-1} \mathrm{~K}^{-1}$ at the forest and $2.93( \pm 0.80) \mathrm{W} \mathrm{m}^{-1} \mathrm{~K}^{-1}$ at the pasture, while during the dry season (Table 8 , lower part) they were equal to, respectively, $0.91( \pm 0.58) \mathrm{W} \mathrm{m}^{-1}$ $\mathrm{K}^{-1}$ and $1.82( \pm 0.28) \mathrm{W} \mathrm{m}^{-1} \mathrm{~K}^{-1}$. The decline in $\lambda$ between wet and dry periods corresponds to a decrease of $0.12 \mathrm{~m}^{3} \mathrm{~m}^{-3}$ and $0.16 \mathrm{~m}^{3} \mathrm{~m}^{-3}$ in the average soil moisture content for the $0.10-0.40 \mathrm{~m}$ soil layer at the forest and the pasture, respectively.

\section{Conclusions}

[33] The wet period was characterized by dense cloud covers at both sites, which were heavier and more variable along the daylight hours at the forest, as evi- 


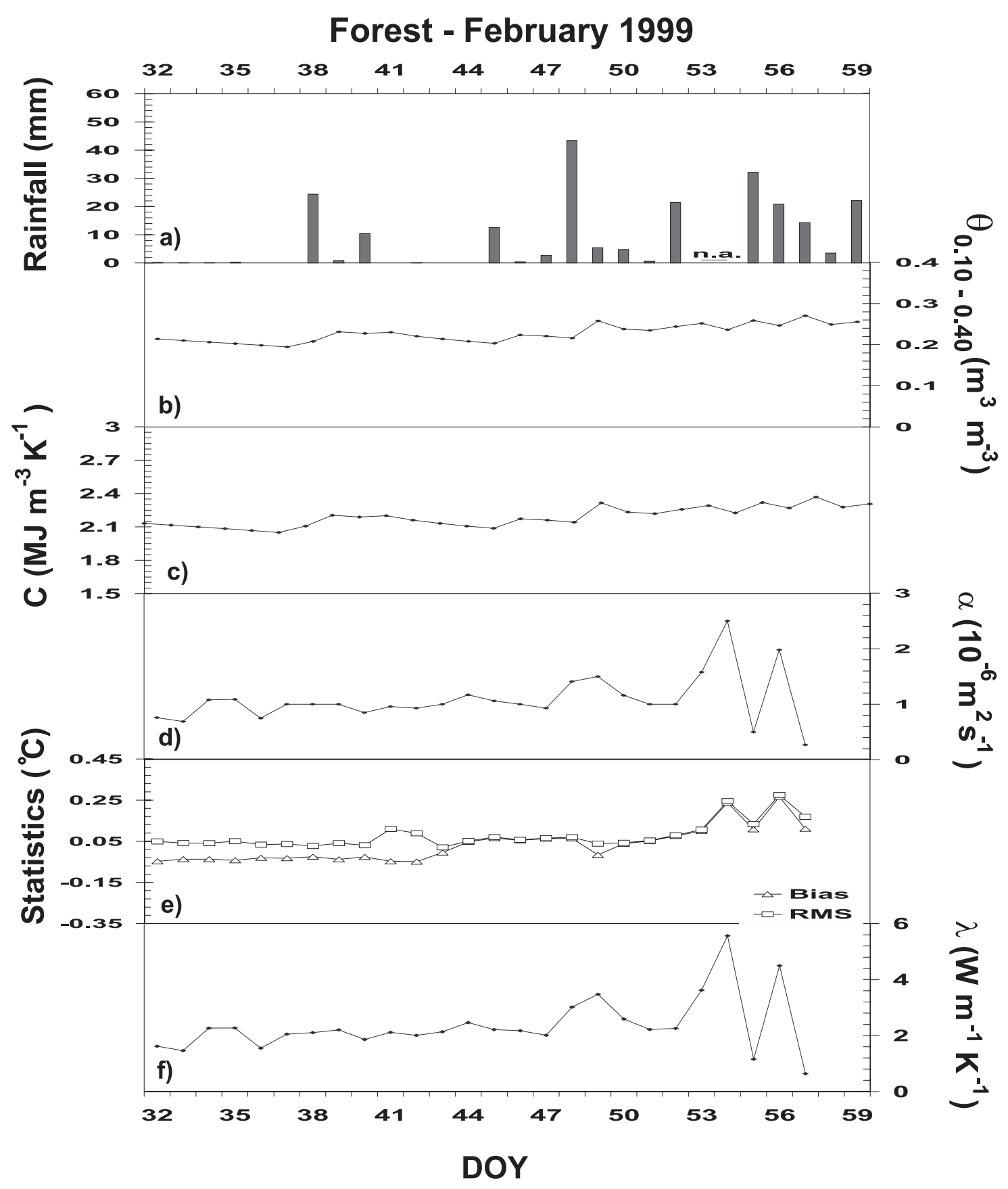

Figure 10. Daily values of (a) rainfall, (b) soil moisture content of the $0.10-0.40 \mathrm{~m}$ layer, $\theta_{0.10-0.40}$, (c) volumetric heat capacity, $\mathrm{C}$, (d) apparent soil thermal diffusivity, $\alpha$, (e) temperature prediction statistics for the $0.20 \mathrm{~m}$ soil depth, and (f) soil thermal conductivity at the forest, February 1999.

denced by the average daily accumulated incident solar radiation. During the dry period, with less dense cloud covers, this pattern was reversed, with lighter and less variable cloud covers at the forest. The average daily accumulated net radiation showed a pattern similar to the one of the average daily accumulated solar radiation, except for a smaller variance at the pasture during the dry period. The ratio between them was higher at both sites during the wet period than at the dry period, with greater values at the forest during a given period. The absolute values of the extrema of the ratio between the daily accumulated soil heat flux and the daily accumulated net radiation were greater at the pasture, due to its smaller vegetation cover; notwithstanding at the forest a negative minimum of $10 \%$ was observed, which is relevant for the daily surface energy budget.

[34] During the wet period, the soil temperatures and their ranges at the depths of $0.10,0.20$, and $0.40 \mathrm{~m}$, except 


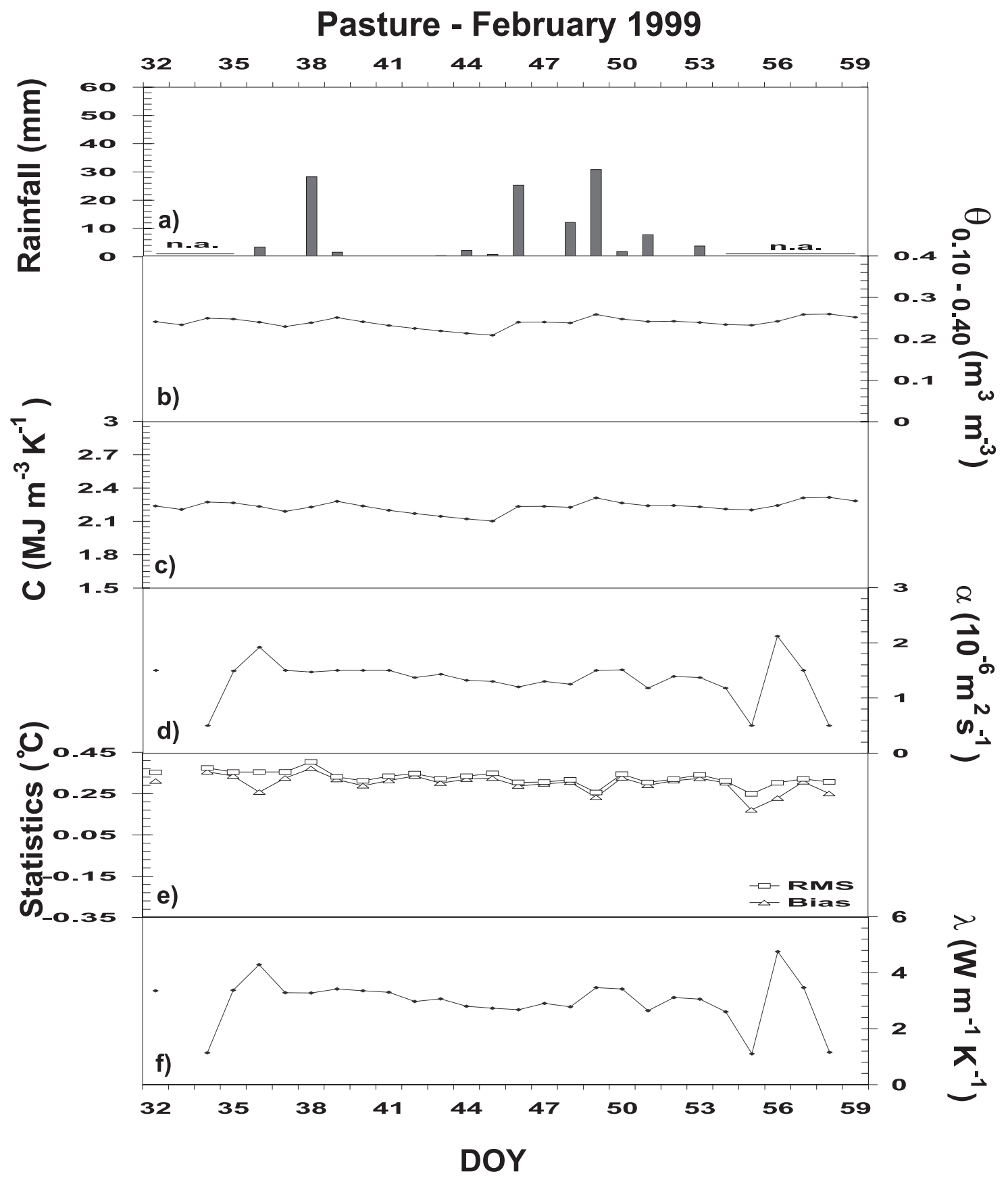

Figure 11. Same as Figure 10 at the pasture, February 1999.

for a $0.10 \mathrm{~m}$ minimum, were smaller at the forest. The soil heat flux presented strong influences of the passage of clouds and rainfalls, intermixed with direct sunshine, with consequent fluctuations of the signal. During the dry period the soil temperature series behavior was similar to the wet one, but without the $0.10 \mathrm{~m}$ minimum. Also, cold fronts left a well delineated signature, especially in the soil temperature series, with strong gradients which may affect the microorganisms in the soil.

[35] Concerning the soil thermal properties, no values were found in the literature for soils covered by dense forests, although, as well highlighted by Sharratt [1997], in studies for others types of forests, the future assessments of heat and water exchange within forests should consider near surface properties of the forest floors. The variations of heat capacity (C) during the dry period at the pasture, with its red-yellow podzol soil, were consistent with the values quoted by Verhoef et al. [1996] for a reddish sandy loam soil of a vineyard in Spain and a loamy soil of a savanna in Niger. The computed apparent soil thermal diffusivities $(\alpha)$ for the pasture confirm the results obtained by Alvalá et al. [1996] for the dry 


\section{Forest -August 1999}

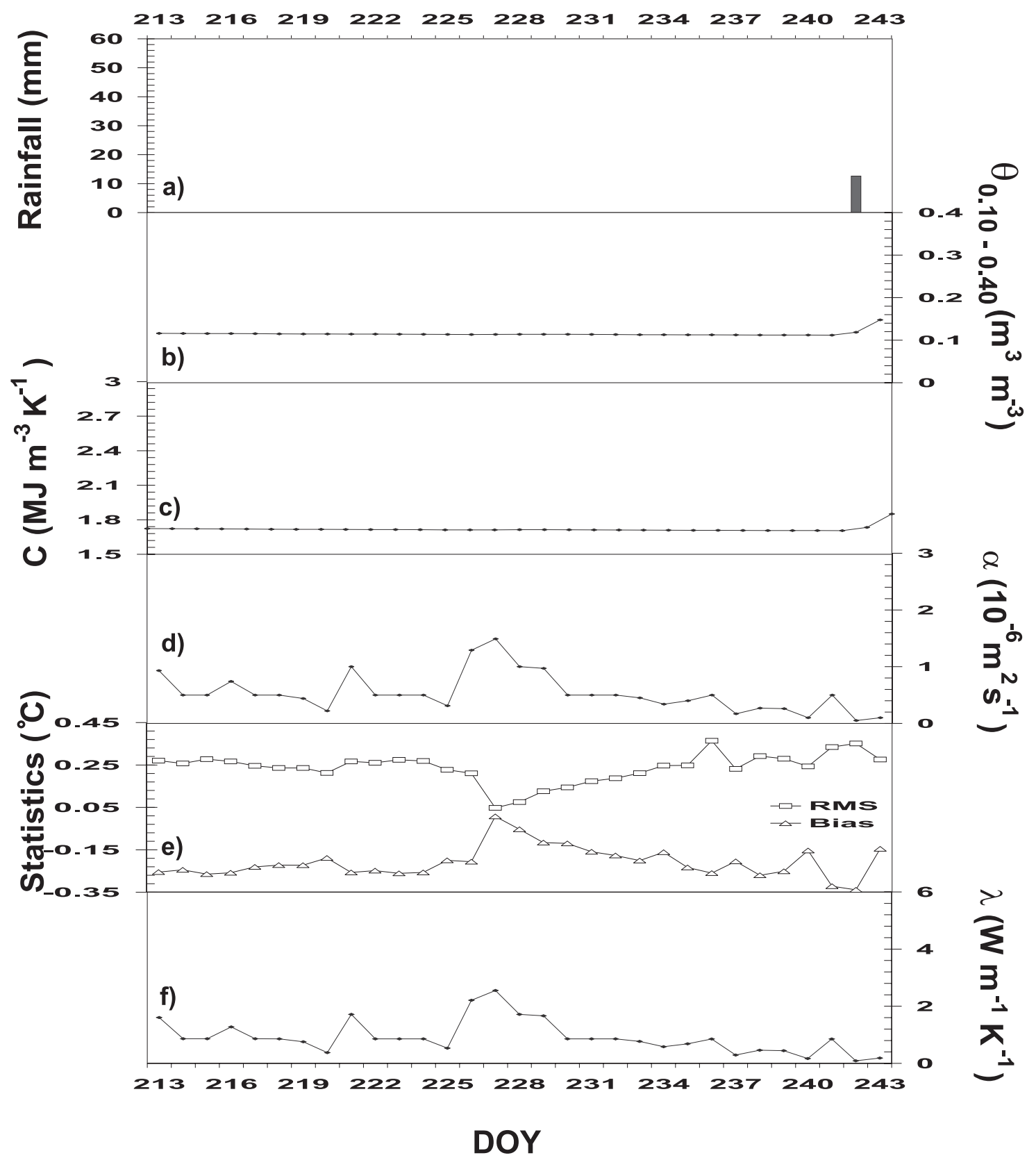

Figure 12. Same as Figure 10 at the forest, August 1999.

period, and are consistent with those of Verhoef et al. [1996] and Passerat de Silans et al. [1996] for low moisture content at savannas. However, they are higher than the values for wet sand given by Rosenberg et al. [1983] and Arya [1988]. The computed apparent soil conductivity $(\lambda=\mathrm{C} \alpha)$ values were consistent with the ones measured by Verhoef et al. [1996], except at the pasture during the wet season, whose values were also higher than the ones recorded by Riha et al. [1980] for sand under wet conditions.
[36] The results show that there are differences in the fluxes, temperature and soil thermal properties between the sites studied, mostly due to their distinct present vegetation covers. Also, they provide useful data to verify weather and climate atmospheric models, as well as to subsidize studies of soil biology, which depend on the thermal behavior of the soils and their water content. Finally, they indicate that further studies, including with measurements of the soil thermal properties, should be made at both sites, as well as in other Amazonian sites with different soil types. 


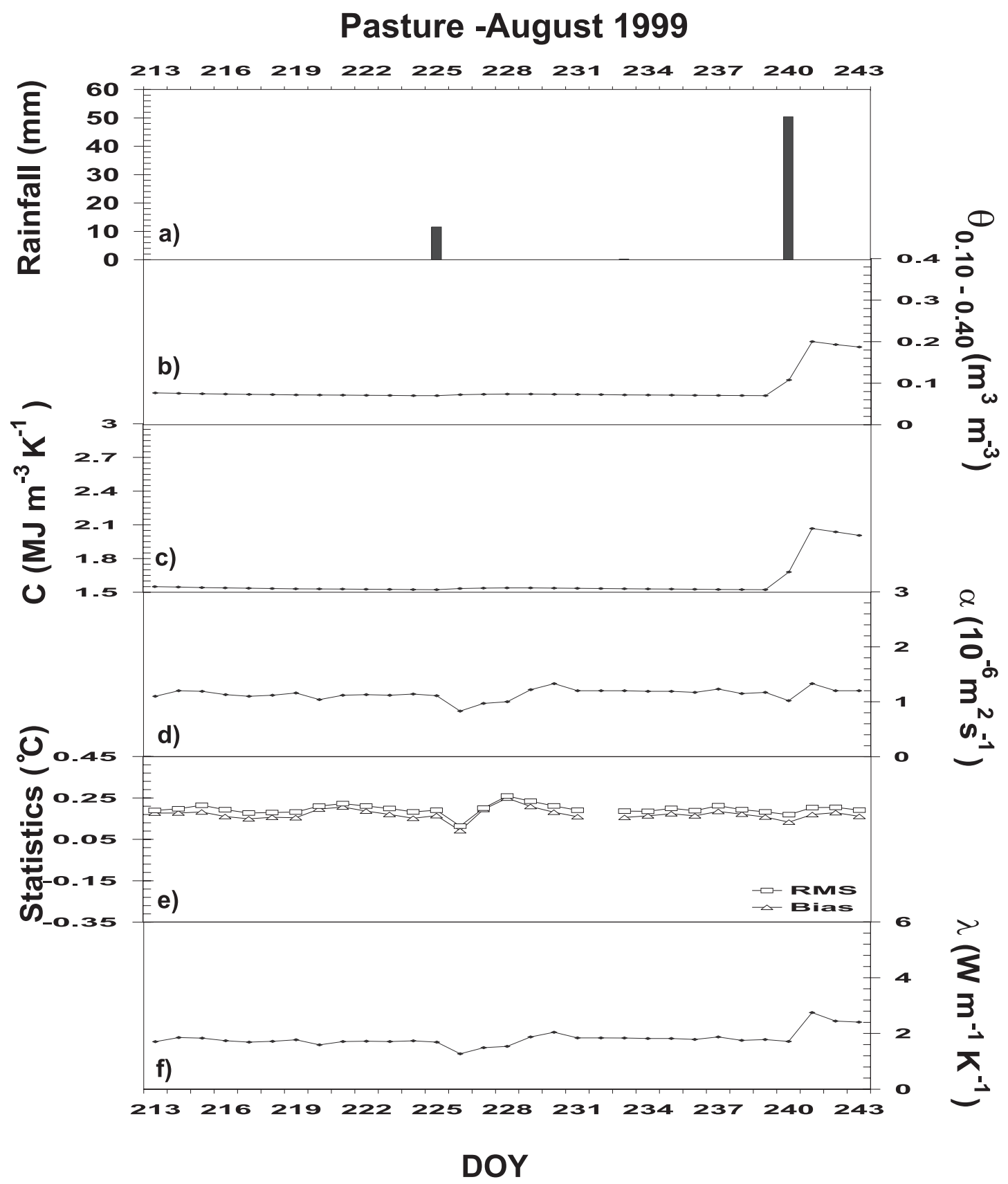

Figure 13. Same as Figure 10 at the pasture, August 1999.

Table 8. Monthly Statistics of Daily Soil Thermal Properties at the Forest and the Pasture During the Wet (DOYs 32-59) and Dry Period (DOYs 213-243)

\begin{tabular}{|c|c|c|c|c|c|c|c|c|}
\hline & $\begin{array}{c}\theta_{0.10-0.40 \mathrm{~m}}, \\
\mathrm{~m}^{3} \mathrm{~m}^{-3}\end{array}$ & $\begin{array}{c}\mathrm{C}, \\
\mathrm{MJ} \mathrm{m}^{-3} \mathrm{~K}^{-1}\end{array}$ & $\begin{array}{r}\alpha \times 10^{6}, \\
\mathrm{~m}^{2} \mathrm{~s}^{-1},\end{array}$ & $\begin{array}{c}\lambda, \\
\mathrm{W} \mathrm{m}^{-1} \mathrm{~K}^{-1}\end{array}$ & $\begin{array}{c}\theta_{0.10-0.40 \mathrm{~m}}, \\
\mathrm{~m}^{3} \mathrm{~m}^{-3}\end{array}$ & $\begin{array}{c}\mathrm{C}, \\
\mathrm{MJ} \mathrm{m}^{-3} \mathrm{~K}^{-1}\end{array}$ & $\begin{array}{r}\alpha \times 10^{6}, \\
\mathrm{~m}^{2} \mathrm{~s}^{-1}\end{array}$ & $\begin{array}{c}\lambda, \\
\mathrm{W} \mathrm{m}^{-1} \mathrm{~K}^{-1} \\
\end{array}$ \\
\hline & \multicolumn{4}{|c|}{ Forest, February 1999} & \multicolumn{4}{|c|}{ Pasture, February 1999} \\
\hline Average & 0.23 & 2.19 & 1.08 & 2.26 & 0.24 & 2.23 & 1.34 & 2.93 \\
\hline STD & 0.02 & 0.09 & 0.44 & 0.53 & 0.01 & 0.05 & 0.37 & 0.80 \\
\hline Max & 0.27 & 2.37 & 2.50 & 3.62 & 0.26 & 2.32 & 2.12 & 4.75 \\
\hline \multirow[t]{2}{*}{ Min } & 0.19 & 2.05 & 0.27 & 1.46 & 0.21 & 2.10 & 0.50 & 1.10 \\
\hline & \multicolumn{4}{|c|}{ Forest, August 1999} & \multicolumn{4}{|c|}{ Pasture, August 1999} \\
\hline Average & 0.11 & 1.72 & 0.55 & 0.91 & 0.08 & 1.59 & 1.16 & 1.82 \\
\hline STD & 0.01 & 0.02 & 0.33 & 0.58 & 0.04 & 0.15 & 0.14 & 0.28 \\
\hline Max & 0.15 & 1.85 & 1.49 & 2.55 & 0.20 & 2.07 & 1.69 & 2.75 \\
\hline Min & 0.11 & 1.70 & 0.10 & 0.09 & 0.07 & 1.52 & 0.83 & 1.27 \\
\hline
\end{tabular}

STD, standard deviation. 
Table 9. Bias and RMS Statistics Between Measured and Predicted Soil Temperatures at the $0.20 \mathrm{~m}$ Depths of the $0.10-0.40 \mathrm{~m}$ Layer

\begin{tabular}{|c|c|c|c|c|c|c|c|c|}
\hline & \multicolumn{2}{|c|}{ Forest, wet } & \multicolumn{2}{|c|}{ Pasture, wet } & \multicolumn{2}{|c|}{ Forest, dry } & \multicolumn{2}{|c|}{ Pasture, dry } \\
\hline & $\begin{array}{c}\text { Bias, } \\
{ }^{\circ} \mathrm{C}\end{array}$ & $\begin{array}{c}\mathrm{RMS}, \\
{ }^{\circ} \mathrm{C}\end{array}$ & $\begin{array}{c}\text { Bias, } \\
{ }^{\circ} \mathrm{C}\end{array}$ & $\begin{array}{c}\mathrm{RMS}, \\
{ }^{\circ} \mathrm{C}\end{array}$ & $\begin{array}{c}\text { Bias, } \\
{ }^{\circ} \mathrm{C}\end{array}$ & $\begin{array}{c}\text { RMS, } \\
{ }^{\circ} \mathrm{C}\end{array}$ & $\begin{array}{c}\text { Bias, } \\
{ }^{\circ} \mathrm{C}\end{array}$ & $\begin{array}{c}\mathrm{RMS}, \\
{ }^{\circ} \mathrm{C}\end{array}$ \\
\hline Average & 0.03 & 0.08 & 0.30 & 0.33 & -0.21 & 0.24 & 0.17 & 0.20 \\
\hline STD & 0.08 & 0.06 & 0.04 & 0.03 & 0.07 & 0.07 & 0.03 & 0.03 \\
\hline Max & 0.27 & 0.27 & 0.37 & 0.40 & 0.01 & 0.36 & 0.25 & 0.26 \\
\hline Min & -0.05 & 0.02 & 0.17 & 0.25 & -0.34 & 0.05 & 0.09 & 0.11 \\
\hline
\end{tabular}

STD, standard deviation.

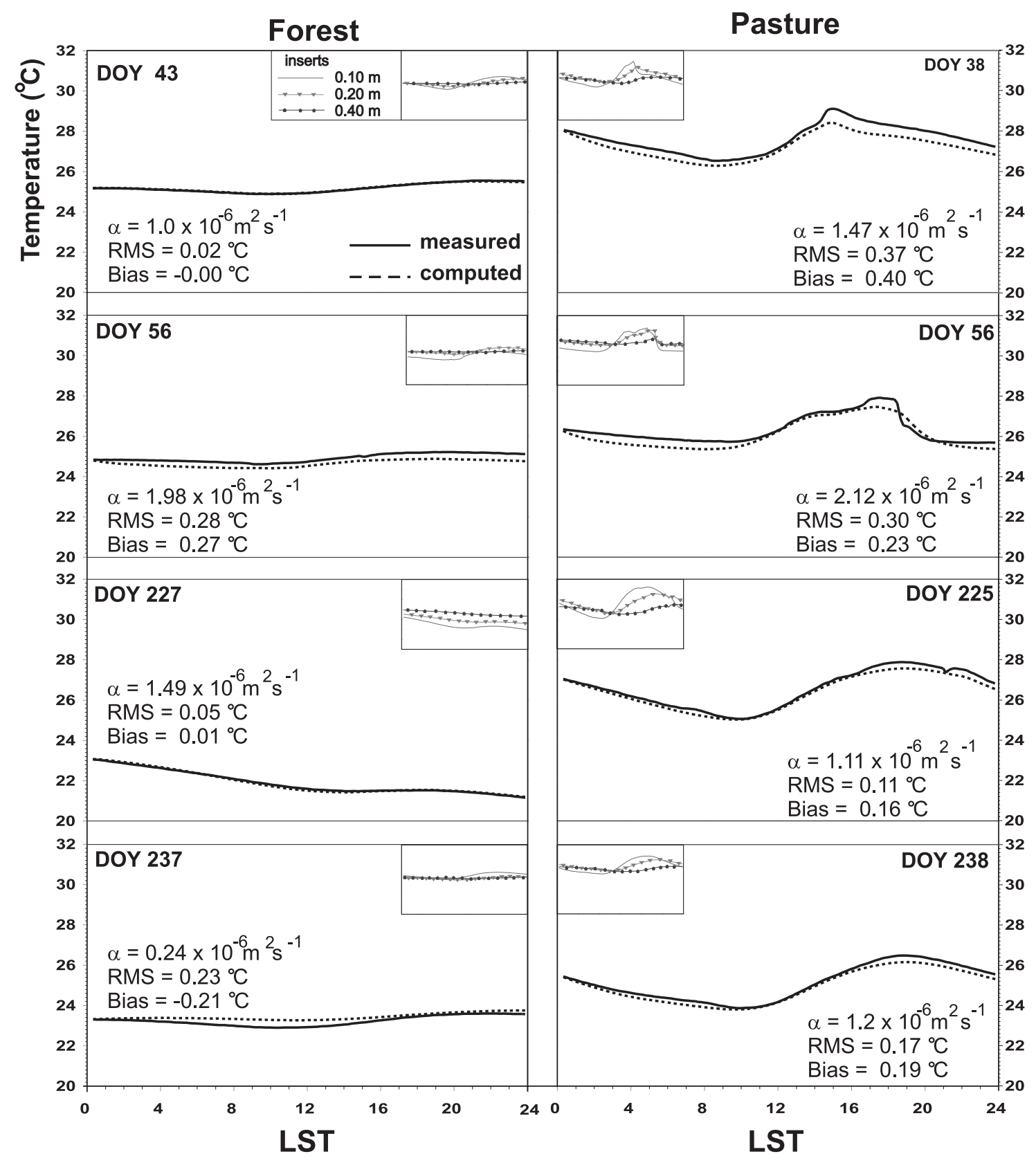

Figure 14. Soil temperatures measured and calculated at $0.20 \mathrm{~m}$ depth at the forest (DOYS 43, 56, 227, 237 ) and at the pasture (DOYS 38, 56, 225, 238). 


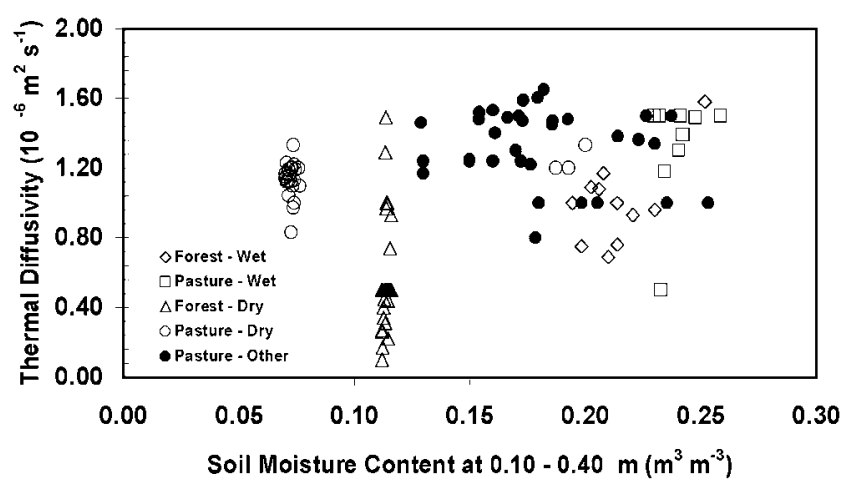

Figure 15. Computed apparent soil thermal diffusivities versus soil moisture content in the $0.10-0.40 \mathrm{~m}$ layer.

[37] Acknowledgments. This work is part of the LBA and was supported by FAPESP (Fundaçäo de Amparo à Pesquisa do Estado de Säo Paulo) grant 1997/9926-9. Thanks are due to J. L. Esteves (INCRA/JiParaná) and C. Brandäo (IBAMA/Ji-Paraná) and their staffs for support during the field campaign. To ULBRA/Ji-Paraná for the soil analyses. To A. I. Harada and S. B. M. Sambatti for data processing. R. C. S. Alvalá, A. O. Manzi, and H. R. Rocha are supported by research fellowships funded by $\mathrm{CNPq} /$ Brazil (Conselho Nacional de Desenvolvimento Científico e Tecnológico).

\section{References}

Alvalá, R. C. S., R. Gielow, I. R. Wright, and M. G. Hodnett, Thermal diffusivity of Amazonian soils, in Amazonian Deforestation and Climate, edited by J. H. Gash et al., pp. 139-150, John Wiley, New York, 1996.

Arya, S. P., Introduction to Micrometeorology, 307 pp., Academic, San Diego, Calif., 1988.

Braud, I., A. C. Dantas-Antonino, M. Vauclin, J. L. Thony, and P. Ruelle, A simple soil plant atmosphere transfer model (SiSPAT): Development and field verification, J. Hydrol., 166, 213-250, 1994.

Calvet, J.-C., R. Santos-Alvalá, G. Jaubert, C. Delire, C. Nobre, I. Wright, and J. Noilhan, Mapping surface parameters for mesoscale modeling in forested and deforested southwestern Amazonia, Bull. Am. Meteorol. Soc., 78, 413-423, 1997.

Campbell, G. S., Soil Physics With Basic Transport Models for Soil-Plant Systems, 1st ed., 155 pp., Elsevier Sci., New York, 1985.

de Vries, D. A., Thermal properties of soils, in Physics of Plant Environment, 2nd ed., edited by W. R. van Wijk, pp. 210-235, North-Holland, New York, 1966.

Hodnett, M. G., M. D. Oyama, and J. Tomasella, Comparisons of long-term soil water storage behaviour under pasture and forest in three areas of Amazonia, in Amazonian Deforestation and Climate, edited by J. H. Gash et al., pp. 57-77, John Wiley, New York, 1996.

Horton, P., P. J. Wierenga, and D. R. Nielsen, Evaluation of methods for determining the apparent thermal diffusivity of soil near the surface, Soil Sci. Soc. Am. J., 47, 25-32, 1983.

INPE, Boletim de monitoramento e análise climática, Climanálise, 14(8), 1999.

Lettau, H. H., Improved models of thermal diffusion in the soil, Trans. $A G U, 35,121-132,1954$.

McWilliam, A.-L. C., O. M. R. Cabral, B. M. Gomes, J. L. Esteves, and
J. R. Roberts, Forest and pasture leaf gas exchange in south-west Amazonia, in Amazonian Deforestation and Climate, edited by J. H. Gash et al., pp. 265-285, John Wiley, New York, 1996.

Nassar, J. N., and R. Horton, Determination of the apparent thermal diffusivity of a nonuniform soil, Soil Sci., 147, 238-244, 1989.

Novak, M. D., and T. A. Black, Theoretical determination of the surface energy balance and thermal regimes of bare soils, Boundary Layer Meteorol., 33, 313-333, 1985.

Passerat de Silans, A. M. B., L. Bruckler, J. L. Thony, and M. Vauclin, Numerical modeling of coupled heat and water flows during drying in a stratified bare soil: Comparison with field observations, J. Hydrol., 105, $109-138,1989$.

Passerat de Silans, A. M. B., B. A. Monteny, and J. P. Lhomme, Apparent soil thermal diffusivity, a case study: HAPEX-Sahel experiment, Agric. For. Meteorol., 81, 201-216, 1996.

Ralston, A., and H. S. Wilf, Mathematical Methods for Digital Computers, John Wiley, New York, 1964.

Riha, S. J., K. J. McInnes, S. W. Clids, and G. S. Campbell, A finite element calculation for determining thermal conductivity, Soil Sci. Soc. Am. J., 44, 1323-1325, 1980.

Rosenberg, N. J., B. L. Blad, and S. B. Vertma, Microclimate: The Biological Environment, John Wiley, New York, 1983.

Sharratt, B. S., Thermal conductivity and water retention of a black spruce forest floor, Soil Sci., 162, 576-582, 1997.

Smirnova, T. G., J. M. Brown, and S. G. Benjamin, Performance of different soil model configuration in simulating ground surface temperature and surface fluxes, Mon. Weather Rev., 125, 1870-1884, 1997.

Smith, C. B., M. N. Lakhtakia, W. J. Capehart, and T. N. Carlson, Initialization of soil-water content for regional-scale atmospheric prediction models, Bull. Am. Meteorol. Soc., 75, 585-593, 1994.

van Wijk, W. R., and W. J. Derksen, Sinusoidal temperature variation in a layered soil, in Physics of Plant Environment, 2nd ed., edited by W. R. van Wijk, pp. 171-206, North-Holland, New York, 1966.

Verhoef, A., B. J. J. M. van den Hurk, A. F. G. Jacobs, and B. G. Heusinkveld, Thermal soil properties for vineyard (EFEDA-I) and savanna (HAPEX-Sahel) sites, Agric. For. Meteorol., 78, 1-18, 1996.

Wierenga, P. J., D. R. Nielsen, and R. M. Hagan, Thermal properties of a soil based upon a field and laboratory measurements, Soil Sci. Soc. Am. J., 33, 354-360, 1969.

R. C. S. Alvalá and R. Gielow, Centro de Previsão de Tempo e Estudos Climáticos, Instituto Nacional de Pesquisas Espaciais, São José dos Campos, SP, Brazil. (regina@cptec.inpe.br; ralf@cptec.inpe.br)

H. R. da Rocha, H. C. Freitas, and J. M. Lopes, Instituto de Geofísica, Astronomia e Ciências da Atmosfera, Universidade de São Paulo, São Paulo, SP, Brazil. (humberto@ciclone.iag.usp.br; helbercf@ciclone. iag.usp.br; jorgelo@ciclone.iag.usp.br)

A. O. Manzi and C. von Randow, Centro de Previsão de Tempo e Estudos Climáticos, Instituto Nacional de Pesquisas Espaciais, Cachoeira Paulista, SP, Brazil. (manzi@cptec.inpe.br; randow@cptec. inpe.br)

M. A. F. S. Dias, Instituto de Geofísica, Astronomia e Ciências da Atmosfera, Universidade de São Paulo, São Paulo, SP, Brazil. (mafsdia@ master.iag.usp.br)

O. M. R. Cabral, Centro Nacional de Pesquisas do Meio Ambiente, Empresa Brasileira de Pesquisa Agropecuária, Jaguariúna, SP, Brazil. (ocabral@cnpma.embrapa.br)

M. J. Waterloo, Vrije Universiteit Amsterdam, Amsterdam, Netherlands. (watm@geo.vu.nl) 